Review

\title{
Water-Soluble Photoinitiators in Biomedical Applications
}

\author{
Wiktoria Tomal ${ }^{1}$ (D) and Joanna Ortyl ${ }^{1,2, *}$ \\ 1 Faculty of Chemical Engineering and Technology, Krakow University of Technology, Warszawska 24, \\ 31-155 Krakow, Poland; wiktoria.tomal@doktorant.pk.edu.pl \\ 2 Photo HiTech Ltd., Bobrzyńskiego 14, 30-348 Krakow, Poland \\ * Correspondence: jortyl@pk.edu.pl
}

Received: 23 April 2020; Accepted: 3 May 2020; Published: 7 May 2020

check for updates

\begin{abstract}
Light-initiated polymerization processes are currently an important tool in various industrial fields. The advancement of technology has resulted in the use of photopolymerization in various biomedical applications, such as the production of 3D hydrogel structures, the encapsulation of cells, and in drug delivery systems. The use of photopolymerization processes requires an appropriate initiating system that, in biomedical applications, must meet additional criteria such as high water solubility, non-toxicity to cells, and compatibility with visible low-power light sources. This article is a literature review on those compounds that act as photoinitiators of photopolymerization processes in biomedical applications. The division of initiators according to the method of photoinitiation was described and the related mechanisms were discussed. Examples from each group of photoinitiators are presented, and their benefits, limitations, and applications are outlined.
\end{abstract}

Keywords: water-soluble photoinitiators; type I photoinitiators; type II photoinitiators; two-photon initiators (2PP); photopolymerization; biomedical applications; free-radical photopolymerization; cationic photopolymerization

\section{Introduction}

Currently, polymerization processes are one of the most widely used chemical processes in various fields of industry [1,2]. One of the most modern and rapidly developing methods of obtaining polymers is light-induced polymerization, i.e., photopolymerization [3-6]. The technique of converting liquid monomers to solid polymers under the influence of applied light is widely developed in the polymer materials sector in the industry of solvent-free paints [7], varnishes [8], and adhesives [9], in optoelectronics [10], in the printing industry for 3D printing materials [11-17], and many others. Numerous advantages of photopolymerization, such as performing reactions at ambient temperature, lack of solvents, and extremely short processing times, made light-initiated polymerization perfectly suited for biomedical applications (Figure 1) [18,19].

The global market for photopolymerization in biomedical applications can be divided into various groups based on the area of application in the medical sector. The main segments are: dentistry [20-23], tissue engineering [24-29], bioimaging [30,31], drug delivery systems [32-35], and medical devices. In dentistry, photochemical-initiated processes are used for the filling of hard dental tissue cavities with photocured polymer composites [36-39]. An interesting application of photopolymerization processes is the production of photo-crosslinked polymeric biomaterials especially those based on totally or partially degradable materials [40-44], scaffolds for tissue culture [45-49], and diagnostic genetic or cellular matrixes [50-58]. 

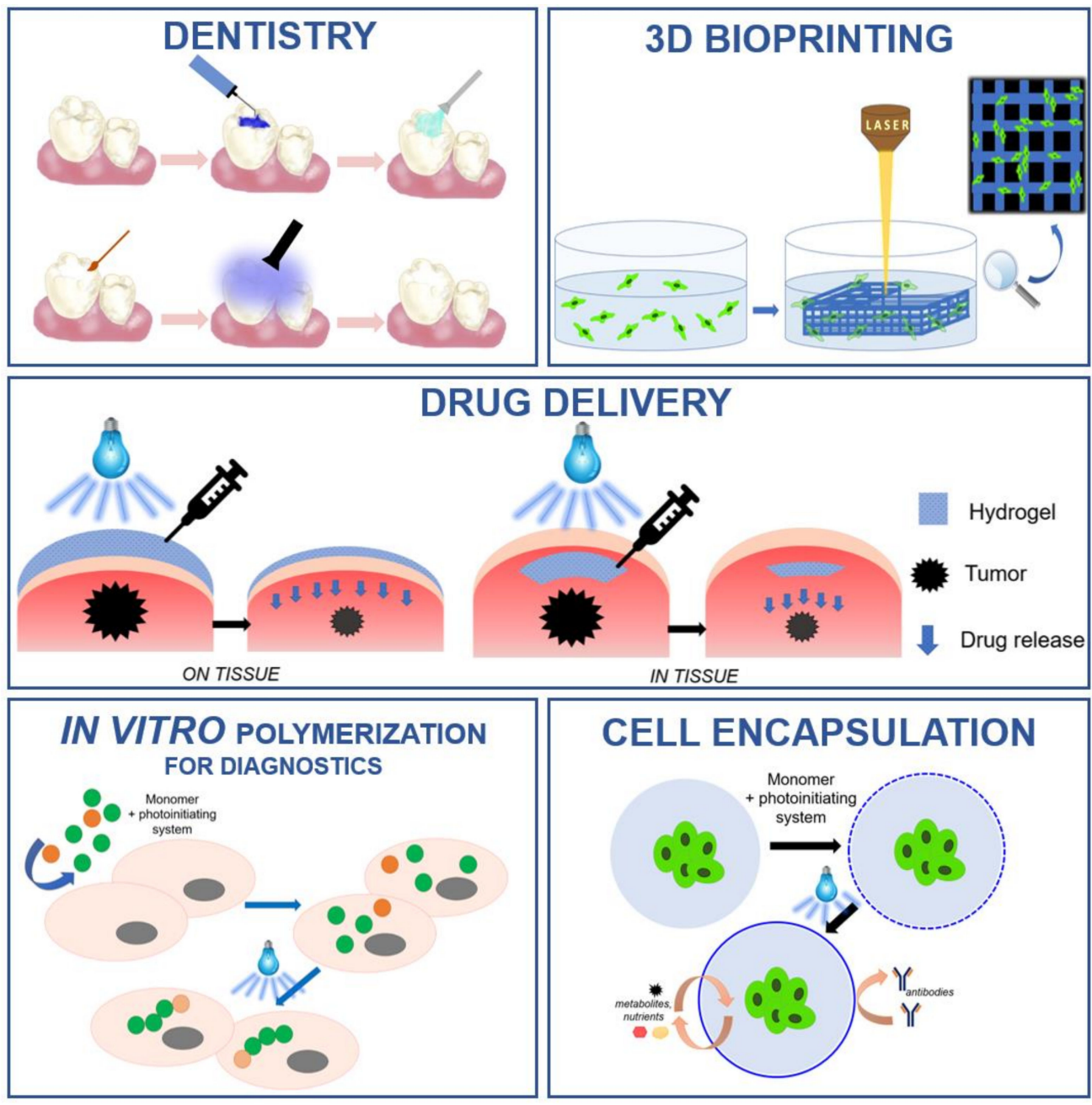

Figure 1. Examples of light-induced polymerization processes in biomedical applications.

The unquestionable advantages of the photopolymerization technique in the context of applications in tissue engineering and biomedical science are primarily its ability to form structures of any geometry as well as the deposition of such materials on various carriers. Lack of these possibilities is often a limitation of the functionality of biomaterials obtained through conventional polymerization processes.

Due to the mechanisms of polymerization as well as the type of used monomers and initiating systems, there is a distinction between radical photopolymerization and cationic photopolymerization, which are the basic processes used in light-initiated polymerization technologies. Radical photopolymerization is a chain reaction consisting of three main stages: initiation, propagation, chain growth, and termination (which may be accompanied by side reactions) [59]. Free-radical photopolymerization is mainly used for acrylate and methacrylate monomers. The factor that limits the usefulness of radical photopolymerization is the occurrence of oxygen inhibition caused by the presence of atmospheric oxygen during the polymerization process. The negative influence of oxygen on polymerization is reflected, for example, by extinguishing the excited states of the initiator, which, in turn, affects the efficiency of the whole process. It is the free-radical polymerization, however, that is mostly used in biomedical applications, as proven by numerous literature reports [60-64].

The second type of polymerization is cationic photopolymerization, which is particularly interesting and relatively widespread in industrial applications, since it has a number of major advantages that make this process practical [65]. The living nature of cationic photopolymerization guarantees that the reaction continues to be effective even after shutting down the radiation source [66]. This enables a high degree of conversion to be achieved, which plays an extremely important 
role in the industrial practice. For this reason, photoinitiated cationic polymerization is becoming increasingly prevalent in global markets as an easy and energy-saving method for obtaining cross-linked polymers $[67,68]$. Despite its numerous advantages, cationic polymerization is very unlikely to be used in biomedical applications. One of the reasons is that cationic initiators generate strong protonic acids during initiation, whose acidic character negatively affects cell cultures [69]. The second reason is the sensitivity of cationic photopolymerization to moisture and water. Numerous scientific articles prove that the presence of water slows down or inhibits the polymerization reaction [70]. In addition, water can act as a chain transfer agent and promote the growth of new chains, which reduces the average molecular weight of the obtained polymer [71].

One of the basic requirements of photocuring systems used in biomedical sciences is their total or partial solubility in water. Water-based photocuring systems have already garnered interest since the late 1970s. Even then, it was well known that the use of water as a non-toxic, green, and cheap solvent was the solution to many problems related to the classical, organic compositions [72]. In addition, aqueous formulations can, in many cases, provide a reaction efficiency that cannot be achieved with conventional organic systems. Interestingly, the oxygen concentration in aqueous systems is an inch lower than in organic preparations, which significantly reduces oxygen inhibition for radical photopolymerization processes. Therefore, the use of water-soluble photoinitiators in aqueous systems for light-initiated polymerization is of great importance in the rapidly growing medical industry, and this article provides an overview of the literature related to the development of water-soluble initiators and their use in biomedical applications.

\section{The Dynamics of the Development of Water-Soluble Photoinitiators}

The key role in light-initiated polymerization processes is played by the initiating system, which influence, among others, the speed of polymerization and the degree of monomer conversion. This has led scientists to concentrate on the development of photoinitiators, which poses major challenges. The dynamics of developing water-soluble photoinitiators have been visualised in Figure 2 as the number of articles published in the analysed subject matter between 1970 and 2019.

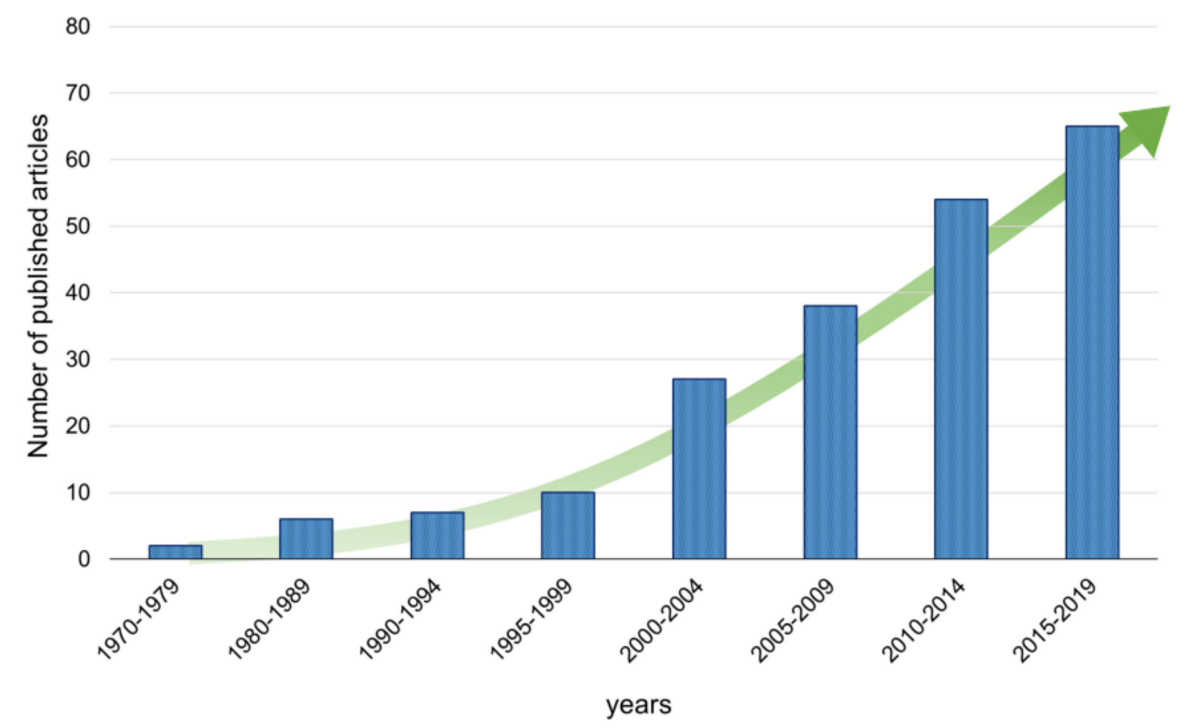

Figure 2. Number of published articles in the years 1970-2019.

As can be seen, photoinitiators have their origins in the 1970s, when waterborne compositions gained popularity in the painting and coating industries, but the increase in water solubility did not always follow the required lack of toxicity of these initiators. A genuine breakthrough was made at the beginning of the 21st century when popular initiators, such as 2-hydroxy-1-[4-(2-hydroxyethoxy) 
phenyl]-2-methyl-1-propanone (Irgacure 2595) and water-soluble derivatives of acylphosphine oxides, e.g., monoacylphosphine oxide (MAPO) and bisacylphosphine oxide (BAPO), were used in new biomedical applications and started to play an important market role. The development of these initiators resulted in an increasing interest in the use of photoinitiated polymerization processes in biomedical applications, which reflects the high level of published scientific articles. Since then, scientists have worked on improving water solubility, initiation efficiency, and cytotoxicity reduction of the initiators discovered in the year 2000. Innovative photoinitiators designed depending on their application, e.g., initiators for two-photon laser polymerization, have also been proposed. An overview of the articles relevant to this topic can be found in the following chapters.

\section{Types of Photoinitiators for Photopolymerization Processes}

The initiating systems based on one-component, two-component, or multi-component photoinitiators undoubtedly play a key role in photopolymerization processes [73-77]. Photoinitiating systems not only determine the mechanism of the reaction, but also affect its performance, curing speed, and final properties of the polymer, such as hardness and viscosity. The selection of a photoinitiator is essential to achieve the right photopolymerization reaction rate and the desired polymer properties. The basic parameters determining the selection of the photoinitiator are maximum absorption wavelength $\lambda_{\max }$ and a molar extinction coefficient $\varepsilon$. The efficiency of the photoinitiator is directly related to its structure, which influences the range of absorption and quantum efficiency of the photochemical and photophysical processes taking place in excited states [78]. Regardless of the type and mechanism of initiation, the photoinitiator should exhibit the following features (Figure 3):

- compatibility between the absorption characteristics of photoinitiators and the emission characteristics of the light source,

- $\quad$ high quantum efficiency,

- good solubility in the polymerized composition - for biomedical applications - and good water solubility,

- non-cytotoxicity,

- should not cause yellowing of the cured product, and

- thermal and temporal stability.

Other factors to be taken into account when performing the photopolymerization reaction are the structure and physicochemical properties of the monomers, the phenomenon of oxygen inhibition (in the case of free-radical polymerization), the influence of stabilisers or other additives present in the monomers, the thickness of the polymerizing layer, the type and intensity of the light source, and the viscosity of the composition.

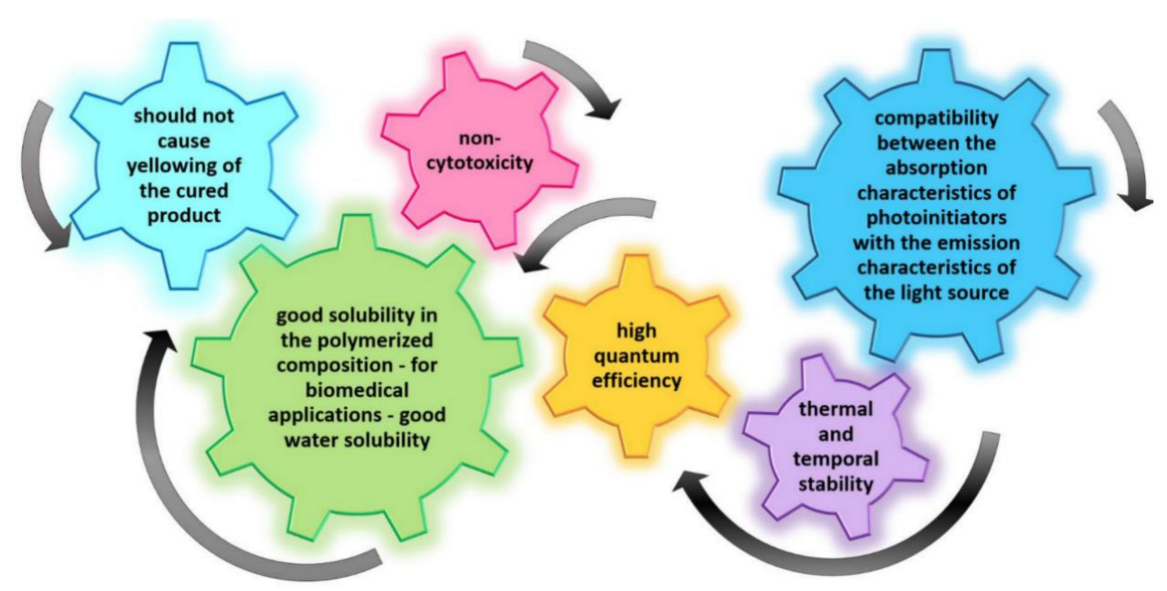

Figure 3. Highlights of initiators' requirements. 
In the case of an in vivo photopolymerization reaction, it is particularly important to reduce the toxicity of the initiator, especially when exposed to light. Free radicals produced during initiation may react with the main components of living cells, such as proteins and nucleic acids, which may affect the condition and viability of cells. Based on the mechanism of initiation of photoinitiators, a distinction is made between radical and cationic photoinitiators. In biomedical applications, radical photopolymerization processes are dominant.

Free-radical photopolymerization is an example of a classic photochemical chain reaction in three main stages: initiation, propagation, and termination, which leads to the formation of oligomers or polymers $[79,80]$. Depending on the structure of a radical photoinitiator, free radicals may be formed in the process of homolytic photodissociation of the photoinitiator molecule - type I photoinitiators. This group of photoinitiators includes peroxides, peresters, iminosulphones, or ketones, where photofragmentation is performed by binding, for example, O-O, S-S, S-N or C-C at $\alpha$ or $\beta-$ carbon atom to the carbonyl group [69]. In the case of Type II photoinitiators, the excited initiator molecule reacts with the appropriate co-initiator such as an electron donor or acceptor or a hydrogen donor in order to produce the appropriate radicals or radical-ions [81]. The photo initiation process using type I or type II initiators is presented in Figure 4. Types I and II photo initiations are singleand two-molecular processes, respectively. The second type is usually slower and less efficient due to the presence of competitive processes during the excitation of the photoinitiator by the monomer, co-initiator, and atmospheric oxygen. Conversely, the photon energy in the visible range is generally lower than the dissociation energy of individual organic compound bonds. Therefore, it is particularly difficult to obtain a highly efficient initiator operating in the visible range. Because of that, it is often in this range that the bimolecular systems are used.

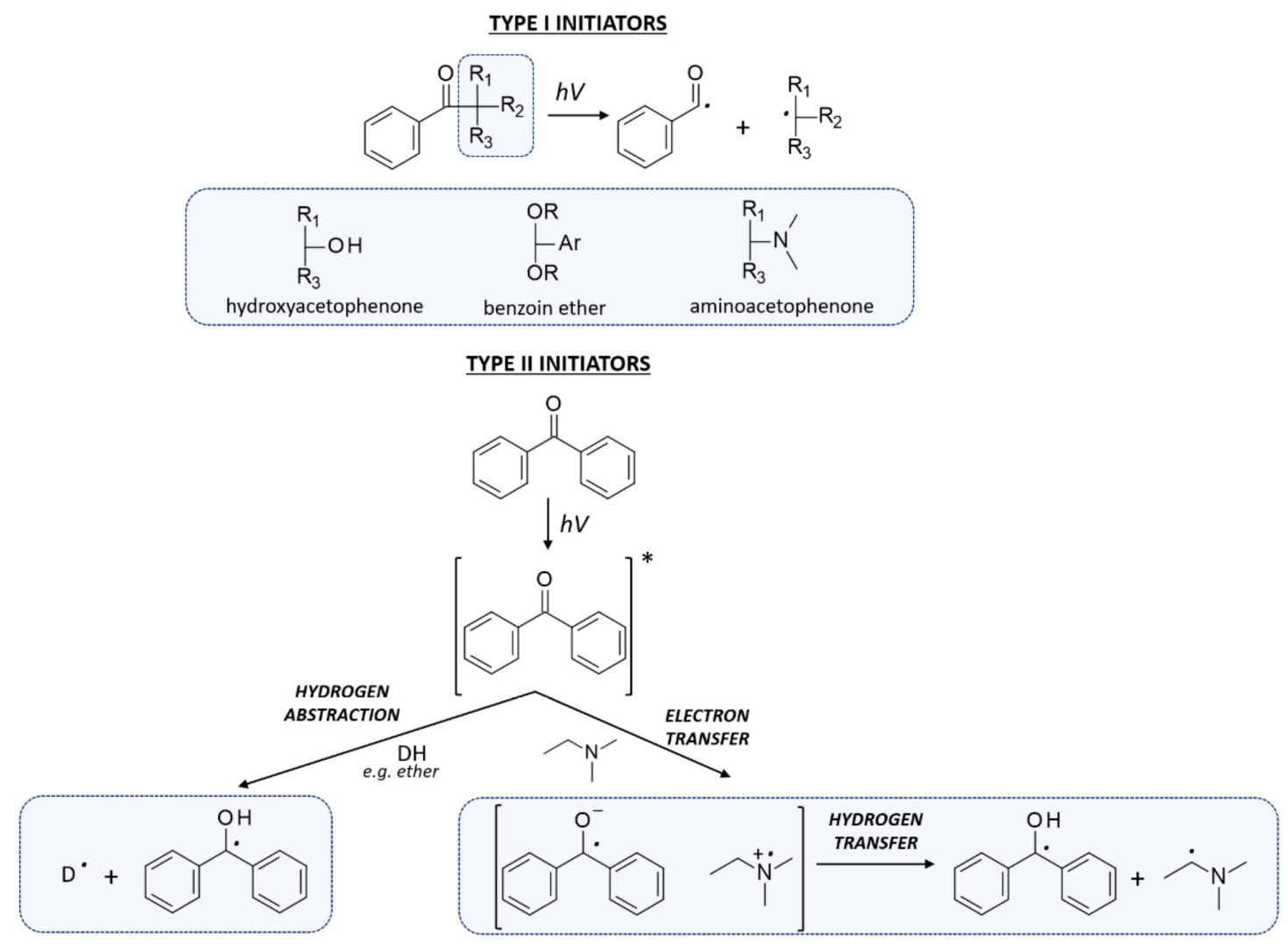

Figure 4. The photo initiation process using: A. type I initiator, B. type II initiator.

Currently, multi-component photoinitiation systems, based on electron transfer, and systems based on hydrogen abstraction, are interesting options. The reaction of electron transfer is based on the 
interaction of an excited electron donor or acceptor with a second component (electron acceptor or donor respectively) in the ground state, which is responsible for the photoinduced electron transfer process. An excited photosensitiser molecule, as the primary light absorber in multiradical systems, can perform a dual role (Figure 5) [82]:

- where the photosensitiser acts as an electron donor, the transfer of the electron to the co-initiator creates a cationic radical of the sensitizer particle and an anionic radical of the co-initiator;

- where the photosensitiser is an electron acceptor, it undergoes photoreduction, and the electron transfer products are the anionic radical formed on the sensitizer molecule and the cationic radical formed on the co-initiator.

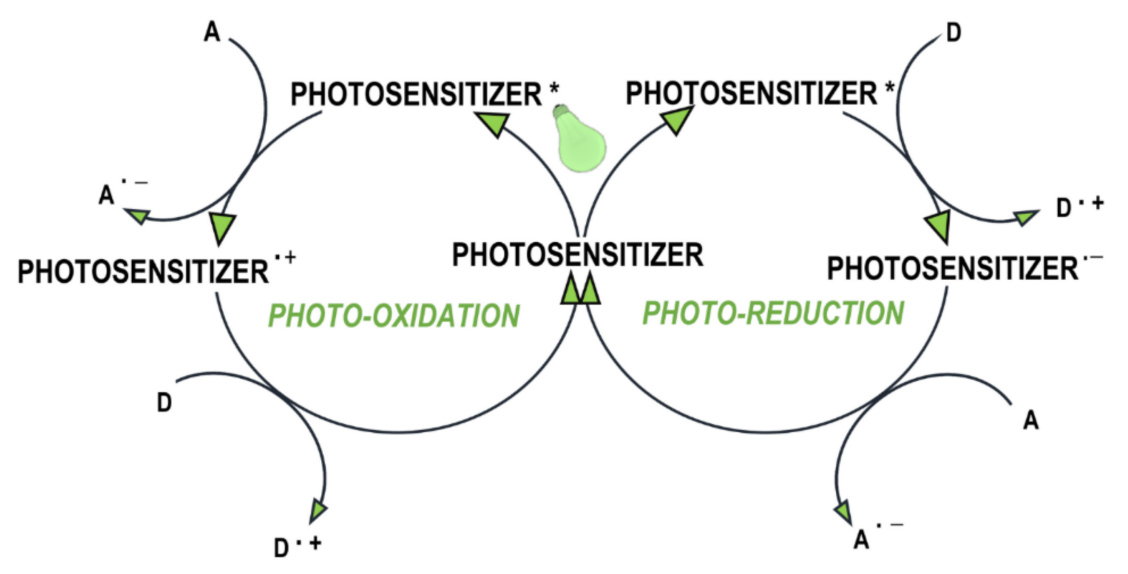

Figure 5. Initiation in multi-component systems: D - electron donor, A - electron acceptor.

In addition to the classic single, binary, and multi-component photoinitiators, there are also two-photon initiators (2PP) that undergo two-photon polymerization. This type of process is a powerful tool to build a variety of 3D matrices with micro-accuracy and nano-accuracy. A two-photon polymerization process is characterised by high penetration depth and high spatial selectivity. In this case, it is possible to use live cells to create 3D structures, thanks to the use of low-energy photons, which are safe for cells $[83,84]$. Two-photon photoinitiators should be sensitive to absorption because, during the initiation, they absorb two photons from the near infrared (NIR) area. In addition, they are characterised by highly conjugated $\pi$-systems and strong donor-acceptor groups [85]. The initiation process is not fully clarified, but it is suspected that, after absorbing the photons, the electron is transferred from the initiator's donor-acceptor group to the $\pi$-electron core [86]. The transfer of the electron between the initiator and the monomer generates an exciplex and results in the formation of radicals that initiate the polymerization reaction (Figure 6) [87].

$$
D-\pi-D \stackrel{2 h V}{\longrightarrow}\left[D-\pi^{*}-D\right] \stackrel{D}{\longrightarrow}\left[D-\pi^{--}-D^{+}\right] \stackrel{[\text { [monomer }]}{\longrightarrow}\left[\text { monomer } \dot{r}^{-}\right]\left[D-\pi-D^{++}\right]
$$

Figure 6. Schematic mechanism of initiation using two-photon photoinitiators.

\section{Type I Initiating System for Free-Radical Photopolymerization}

\section{1. $\alpha$-hydroxyketones and Their Derivatives}

One of the basic methods for increasing the solubility of traditional radical photoinitiators is their chemical modification, which consists of adding appropriate groups to the structure of the photoinitiator [88] [89-91]. The groups designated for this purpose are: non-ionic ethers, polyethers, hydroxyethers [92], ionic substitutes such as quaternary ammonium salts, sulphonates, carboxylic acids, and thiosulphates [93-95]. The most common solubilising group is the hydroxyl group, which can be 
found in the most popular water-soluble initiator: Irgacure 2959 - 2-hydroxy-1-[4-(2-hydroxyethoxy) phenyl]-2-methyl-1-propanone. This initiator contains ketone groups as functional groups and it is one of the first commercially available water-soluble photoinitiators to be used in a variety of areas. Despite its drawbacks, such as low water solubility below $2 \%$ and a narrow absorption range reaching only the UV-A - $365 \mathrm{~nm}$ range, this initiator has become widespread and a range of water-soluble initiators has been created on its core. One of the most important advantages of this group of initiators is the possibility of inexpensively modifying the primary carboxylic group [96-98]. One of the disadvantages of Irgacure 2959, as well as its derivatives, is the need to use UV light. Its maximum absorption is at $276 \mathrm{~nm}$ and, due to its poor absorption, Irgacure 2959 requires extended exposure time. As well known, the use of such a light source for cross-linking processes in biomedical applications has a significant negative impact on the functioning of cells, which causes their mutation or death [99-101]. Other derivatives from the Irgacure family have also been tested for biological purposes, including Irgacure 184 (1-hydroxy-cyclohexyl-phenylketone), Irgacure 369 (2-Benzyl-2-dimethylamino-1-(4-morpholinophenyl)-1-butanone) [102], and Irgacure 907 (2-Methyl-4'-(methylthio)-2-morpholinopropiophenone) [103-105]. Williams et al. compared the cytotoxicity of Irgacure 2959, Irgacure 651 (2,2-dimethoxy-2-phenylacetophenone), and Irgacure 184 [106]. The following relationship has been noted for all initiators. Initiator toxicity grows with increasing concentration of the initiator as well as with increasing exposure time to UV light. Irgacure 2959 turned out to be the best of this group, as the remaining two proved to be toxic to cells at a minimum concentration. The structures of $\alpha$-hydroxyketones and their derivatives are shown in Figure 7.
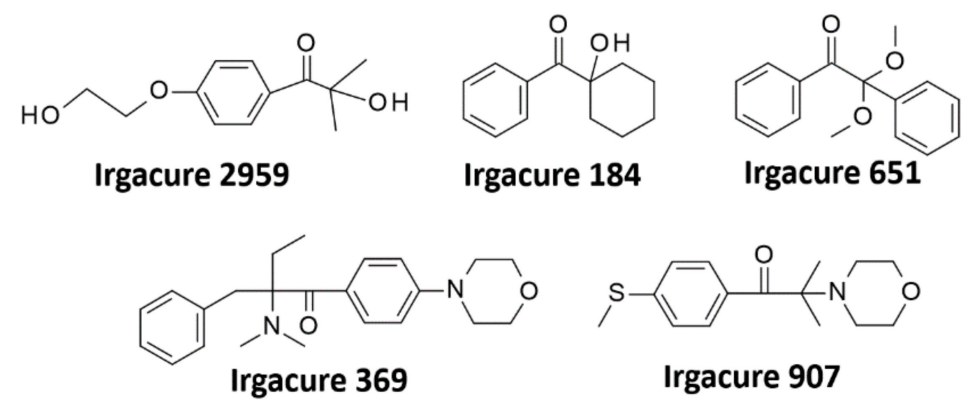

Figure 7. Various initiators from the Irgacure family used in biomedical applications.

Irgacure 2959 is a type I photoinitiator that, when irradiated, cleaves into two radicals, benzoyl and alkyl, which can both initiate a polymerization reaction $[107,108]$. Irgacure 2959 is a widely used photoinitiator for preparing hydrogel materials using poly(ethylene glycol) diacrylate - PEGDA [109-113], gelatin-methacryloyl - GelMA [114,115], and methacrylated hyaluronic acid MeHA [115,116] (Figure 8). This initiator is also used for cell encapsulation [117-121], for the targeted delivery of drugs and cells [122,123], and for the production of scaffolds for cell cultures [124-128].

Liska et al. have developed new water-soluble initiators containing carbohydrate residues and co-polymerising derivatives of these residues. The noted water-soluble initiators consisted of alkylphenones, benzophenones, and thioxanthones, and were accompanied by carbohydrates such as glucose and cellulose [129]. The proposed initiators proved to be highly effective in the initiation process, and those based on known structures, e.g., Irgacure 2959, have great potential in biomedical applications.

Another group of initiators, proposed in 1998 by Kojim et al., are based on 2-benzyl-2-(dimethylamino)1-(4-morpholinophenyl)-1-butanone (BDMB), and more specifically on its water-soluble derivative: sodium 4-[2-(4-morpholino)benzoyl-2-dimethylamino] butylbenzenesulphone (MBS) [130]. Over time, the popularity of the MBS initiator and its modifications led it to find its way into biomedical applications, e.g., the microfabrication of scaffolds [131,132] and the printing of protein microstructures [133]. 
<smiles>C=CC(=C)COCCOC(=O)C=CC</smiles>

PEGDA

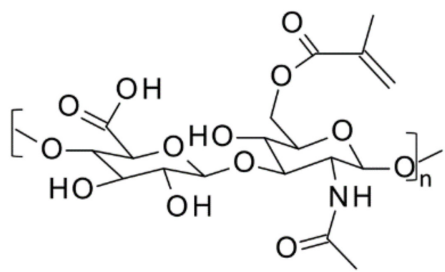

MeHA

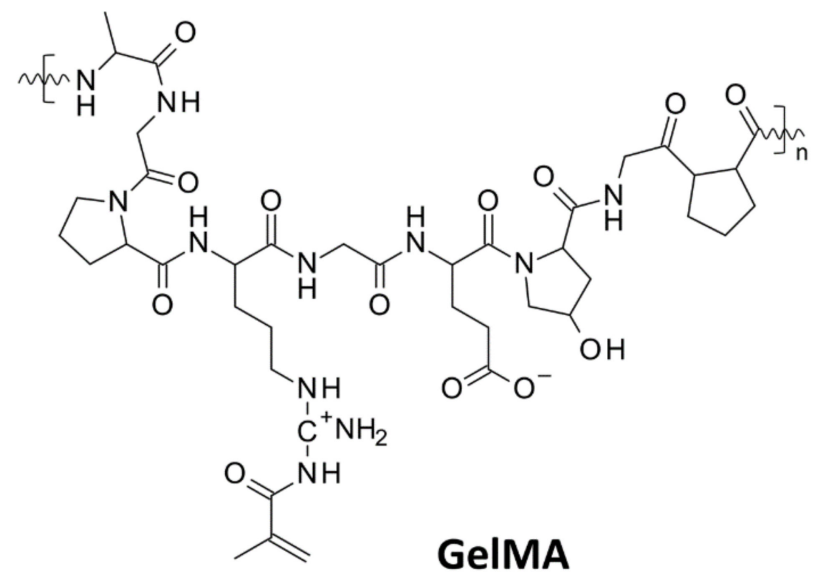

Figure 8. Commonly used monomers for preparing hydrogel materials by a photoinitiated polymerization reaction.

\subsection{Phosphine Derivatives}

Currently, scientists are working on modifying the already known initiators in order to either increase their water solubility or increase their absorption range and, consequently, obtain a fast and efficient initiating system [134]. Mono-acylphosphine oxides (MAPO) and bi-sacylphosphine oxides (BAPO) are mainly water-insoluble initiators that absorb in the $380-450 \mathrm{~nm}$ range. One of the first commercially available mono-acylphosphine initiators is TPO - diphenyl (2,4,6-trimethylbenzoyl)phosphine oxide (Figure 9). This initiator absorbs in the range of $350-380 \mathrm{~nm}$. During initiation, it decays into reactive radicals, which provide high efficiency in the polymerization process. Its advantages also include good thermal stability and lack of colour and odour. This initiator, however, is poorly soluble in an aqueous medium [135].

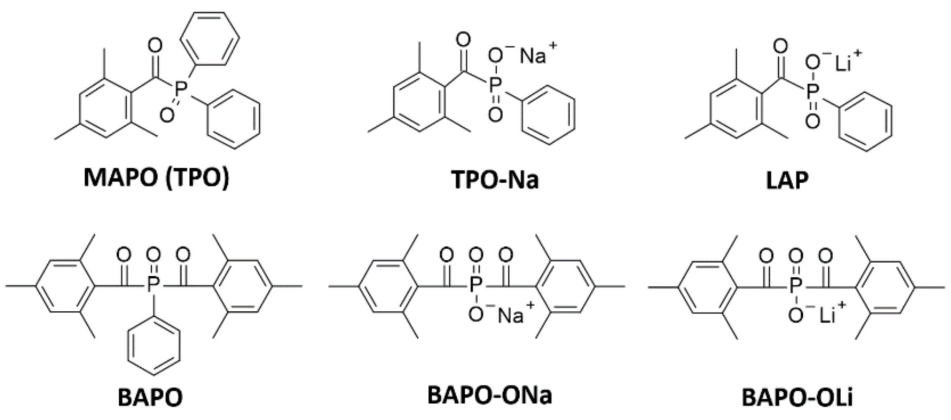

Figure 9. Monoacylphosphine oxide (MAPO) and bisacylphosphine oxide (BAPO) water-soluble derivatives.

Therefore, TPO derivatives with increased water solubility were created. The first reports of water-soluble initiators being TPO derivatives date back to 1991, when Majima et al. synthesised lithium phenyl-2,4,6-trimethylbenzoylphosphinate LAP, which proved to have good spectroscopic properties and high water solubility [136]. Their work was continued by Fairbanks et al. who, in 2009, improved the synthesis of the LAP initiator [137]. LAP is a widely used initiator for obtaining hydrogel materials using: PEGDA [138], GelMA [139], and other monomers [140,141].

Benedikt et al. analysed various modifications of bisacylphosphine oxides and compared the spectroscopic characteristics, polymerization kinetics, and cytotoxicity of the following derivatives: BAPO-OLi and BAPO-ONa (Figure 9) $[142,143]$. Both modifications were suitable as highly effective initiators for obtaining hydrogel materials. Additionally, BAPO-OLi ensured high cell viability [144]. The basic spectroscopic properties of MAPO-based and BAPO-based initiators, as well as the comparison of their solubility and toxicity, are presented in Table 1. Wang et al. performed a modification of BAPO 
by grafting its structure into a polyethylene glycol (PEG) chain, which improved its water solubility and allowed it to print a hydrogel with high optical resolution and good mechanical parameters [145].

Table 1. Comparison of spectroscopic properties, solubility, and toxicity of water-soluble monoacylphosphine oxide (MAPO) and bisacylphosphine oxide (BAPO) derivatives [142].

\begin{tabular}{|c|c|c|c|c|c|}
\hline \multirow[b]{2}{*}{ Initiator } & \multirow[b]{2}{*}{ Derivative of } & \multicolumn{2}{|c|}{ Spectroscopic Properties } & \multirow{2}{*}{$\begin{array}{l}\text { Solubility } \\
{\left[\mathrm{g} / \mathrm{dm}^{3}\right]}\end{array}$} & \multirow{2}{*}{$\begin{array}{c}\text { Toxicity } \\
\text { LC }_{50} \\
{\left[\mathrm{mmol} / \mathrm{dm}^{3}\right]}\end{array}$} \\
\hline & & $\begin{array}{c}\lambda_{\max -\mathrm{ab}} \\
{[\mathrm{nm}]}\end{array}$ & $\begin{array}{c}\varepsilon @ @ \lambda \max -\mathrm{ab} \\
{\left[\mathrm{dm}^{3} \cdot \mathrm{mol}^{-1} \cdot \mathrm{cm}^{-1}\right]}\end{array}$ & & \\
\hline LAP & MAPO & 380.5 & 191 & 47 & 3.1 \\
\hline TPO-Na & MAPO & 380.5 & 250 & 29 & $<0.56$ \\
\hline BAPO-OLi & BAPO & 383.5 & 197 & 54 & 2.6 \\
\hline Bapo-ONa & BAPO & 383.5 & 256 & 60 & 2.8 \\
\hline
\end{tabular}

$\mathrm{LC}_{50}$ - determines cytotoxicity in the cell culture. $\mathrm{LC}_{50}$ corresponds to the concentration of a given medium, which is fatal for $50 \%$ of cells.

In addition, scientists Pawar et al. have developed TPO water-dispersible nanoparticles, characterised by an absorption range of 380-420 nm, while maintaining a high molar excitation coefficient and good solubility in water [146]. TPO nanoparticles were prepared by rapid conversion of volatile microemulsions into water dispersible powder. This is a process that can be applied to various photoinitiators. Neither chemical modification of TPO nor the addition of organic solvents were required to obtain an efficient initiator, which maintains the outstanding spectroscopic properties of the TPO nano initiator and provides efficient 3D printing of hydrogel materials such as the production of highly stretchable hydrogels using digital light processing (DLP) [147].

\subsection{Azo-Initiators}

The water-soluble azo-initiator - 2,2'-azobis[2-methyl-N-(2-hydroxyethyl) promionamide] (VA-086) - becomes increasingly popular because of its low cytotoxicity in both precursor and radical forms, while its absorbance range offers the possibility of using different sources in the far UV range [148]. Occhetta et al., in their research on the production of hydrogel microstructures, have proven that the use of the VA-086 initiator allows for a very high optical resolution printout and also provides a high cell viability rate even after long exposure to light. Occhetta's 3D micro-pellets were not only biocompatible, but also created an environment favourable to proliferation [149].

In turn, Wang et al. proved that the VA-086 initiator has great potential in tissue engineering, where the light source is a laser diode. By appropriately selecting the diameter of the beam and its burning time at one point, the final degree of conversion of the obtained polymeric materials can be controlled [150]. They also proved that the problem of obtaining hydrogel porous materials, caused by nitrogen release during the initiation reaction with the VA-086 initiator (Table 2), can be solved by appropriate exposure time selection. Han et al. proposed a two-component initiating system combining the initiator Irgacure 2959 and VA-086, which resulted in improved mechanical properties of the obtained polymer network, with a minimised radiation dose and reduced exposure time [151].

\section{Type II Initiating System for Free-Radical Photopolymerization}

\subsection{Eosin- $Y$}

Eosin-Y is used as a photoinitiator due to its excellent spectroscopic properties, which makes it suitable for use with light sources in the visible range and safe for living organisms. Eosin- $Y$ is an example of the type II initiator, which needs a second molecule, such as an electron donor, to initiate a polymerization reaction [152] (Figure 10). An example of such a co-initiator, which will be reduced during the reaction, is amine, e.g., triethanolamine. After the absorption of light, eosin is excited to 
a triplet state and then becomes an acceptor of the electron given by the amine. As a result of this process, eosin's radical anion and radical cation of the amine are formed. Then, as a result of proton transfer from the amine radical cation, two neutral radicals are formed: the amino radical and the eosin radical (Table 2) $[153,154]$. Work on the Type II initiating system, Eosin-Y with amine, started in 1991 by Fouassier, Sawhney, et al., during which hydrogels were produced based on polyethylene glycol (PEG) [155]. As an initiating system, Eosin-Y/ethylamine was used in ratios of $0.4 \% \mathrm{w} / \mathrm{v}$ and $3.5 \% \mathrm{w} / \mathrm{v}$, respectively [156]. Eosin has become very popular in the process of surface polymerization for the encapsulation of living cells, including islets of Langerhans [157-159]. Another important application of Eosine-Y is targeted drug delivery [160]. Eosin-Y is a widely used initiator for obtaining hydrogel materials, using mainly poly(ethylene glycol) diacrylate [161,162] and gelatin-methacryloyl [163]. In addition, Shih et al. have proven that Eosin can successfully act as a single-component photo initiating system in a thiol-ene photo-click polymerization reaction [164].

\subsection{Riboflavin $\left(B_{2}\right)$}

Riboflavin is a naturally occurring yellow pigment, which is widely used in biomedical applications due to its high water solubility and biocompatibility [165] (Figure 10). Thus, the use of riboflavin as an initiator for hydrogel production would not only be harmless to cells but even beneficial. Riboflavin's spectroscopic characteristics are favourable. It has a wide absorption range with four maximums: $223 \mathrm{~nm}, 267 \mathrm{~nm}, 373 \mathrm{~nm}$, and $444 \mathrm{~nm}$ [166], and absorbs strongly between 330 and $470 \mathrm{~nm}$, which makes it particularly attractive as an alternative to other synthetic initiators [167].

Riboflavin is a type II photoinitiator, which requires the presence of a co-initiator as an electron donor during the initiation of the polymerization reaction. Therefore, various initiating systems were studied. Bertolotti et al. examined a riboflavin/triethylamine initiation system for the photopolymerization of methacrylate hydrogels, which proved to be very efficient [168-171]. In order to produce a hydrogel free of unnecessary chemicals, however, the scientists proposed to use L-arginine as a co-initiator in the initiation process with riboflavin, since it contains amino groups as amino acids, which are electron donors [172]. Furthermore, in addition to initiating polymerization processes effectively, this co-initiator is biocompatible and well soluble in water. Additionally, it has been proven that the small concentration of riboflavin (0.01-0.5 wt.\%) provides the fastest cross-linking as well as good physicochemical properties for the obtained hydrogel, while using $10 \%$ amine as a co-initiator [165]. The generation of riboflavin radicals and, thus, the reaction rate is also strongly influenced by the applied $\mathrm{pH}$. In addition, it has been proven that following irradiation with visible light and UV light in the presence of oxygen, riboflavin produces reactive oxygen species such as: singlet oxygen, peroxide anion radicals, and others $[173,174]$. As a photoinitiator, riboflavin has already been used in in vivo studies for the treatment of corneal-related diseases, and the resulting hydrogels have proven to have promising physicochemical properties [175].

\subsection{Camphorquinone and Its Modifications}

One of the most popular initiators is camphorquinone (CQ), which belongs to the aliphatic $\alpha$-ketones (Figure 10). The efficiency of this initiator in a one-component system is insufficient, while adding a second component, e.g., in the form of a tertiary amine as an electron donor, increases the efficiency of initiation. The mechanism is based on the process of electron-proton transfer [176]. Such combinations are widely used for the cross-linking of tooth fillings based on methacrylate resins [177]. Unfortunately, as an initiator in the visible range, camphorquinone has its drawbacks. First of all, it gives a strongly yellow product after the polymerization reaction, which makes the end product aesthetically unappealing. Additionally, camphorquinone has poor solubility in water, which limits the possibility of using this initiator to create hydrogel polymer networks [178].

In order to increase the water solubility of camphorquinone, it was modified to obtain carboxylated camphorquinone, while maintaining good spectroscopic properties $[179,180]$. The most commonly used co-initiators with CQ are amines: triethylenamine and ethyl-4- $N, N$-dimethylaminobenzoate 
(Table 2) [181-183]. Ternary initiation systems were also studied, which proved to be very effective and harmless to cells: the initiator, camphorquinone, the co-initiator, amine, and the accelerator, thioxantone or iodine salt $[104,184]$. The main direction of application of this initiator is the production of hydrogels for targeted drug delivery and in situ polymerization [185-189] as well as the production of biodegradable hydrogels for tissue engineering or biocompatible materials for application, e.g., in temporomandibular joints [190,191].

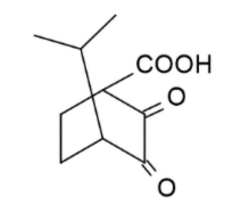

Carboxylated camphorquinone<smiles>O=C(O)c1ccccc1-c1c2cc(Br)c(=O)c(Br)c-2oc2c(Br)c(O)c(Br)cc12</smiles>

Eosin-Y<smiles>Cc1cc2nc3c(=O)[nH]c(=O)nc-3n(CC(O)C(O)C(O)CO)c2cc1C</smiles>

Riboflavin

Figure 10. Type II initiators used in biomedical applications.

\section{Two-Photon Photoinitiators (2PP) for Free-Radical Photopolymerizations in Biomedical Applications}

As mentioned earlier, two-photon polymerization is a powerful tool for building 3D matrices with accuracy even on a nanometric scale, and, at the same time, enables spatial control and high depth of light beam penetration [192]. The light source is used in a near-infrared (NIR) region, which makes it possible to conduct the process in the presence of living cells [193]. The use of two-photon technology has, therefore, attracted significant interest in recent years [194-199]. For this technique, it is essential to select a suitable two-photon initiator which, when used in biomedical applications, must be water soluble, thermally stable, optically stable in the dark, non-toxic, and should generate free radicals easily $[200,201]$. The comparison of one-photon and two-photon polymerization is shown in Figure 11.

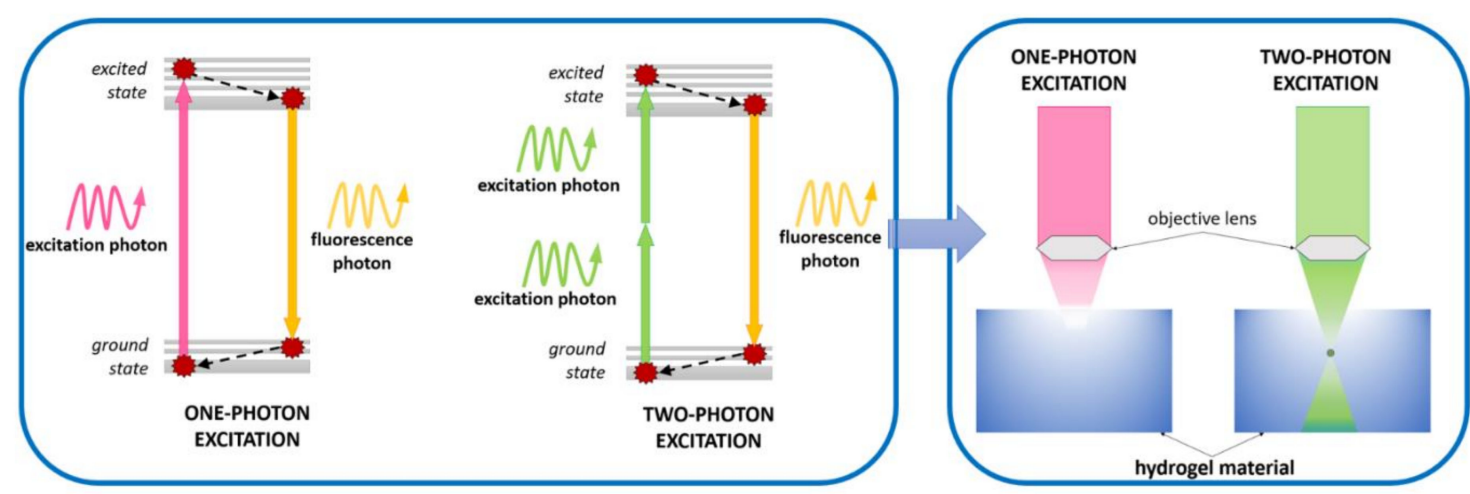

Figure 11. Comparison of one-photon and two-photon polymerizations.

The challenge for two-photon initiators is to increase their water solubility. One of the methods for increasing hydrophilicity is the addition of non-ionic surfactants. Jkaverii et al. carried out two-photon polymerization using a commercially available initiator from the Irgacure family, Irgacure 651, with the addition of a surfactant, AF240 [202]. The disadvantage of this solution is the unfavourable influence of surface agents on the biocompatibility of obtained materials [203]. Initiators that undergo homolytic decay during irradiation, such as LAP [204] or VA-098 presented earlier, are characterised by relatively low $\pi$-system conjugation, poor two-photon absorption, and are, thus, less efficient in processes using laser as an irradiation source [205]. The popular Irgacure 2959 initiator can also be used in this case [206], but it is only suitable for 2PP at $515 \mathrm{~nm}[207,208]$. Chichkov et al. used Irgacure 369 as a $2 \mathrm{PP}$ initiator in order to obtain biocompatible scaffolds. This compound, however, has a 
small cross-section in the NIR range [209] and its absorption maximum is at $369 \mathrm{~nm}$, which makes it inconvenient when using a laser light source in the 750-800 $\mathrm{nm}$ range [210-212]. Some well-known type II initiators, such as Eosin-Y [213], erythrosine [214], and rose Bengal [215-219], in combination with amines, can be used as two-photon initiators of polymerization (Figure 12). The long exposure time and high intensity of radiation, however, makes it necessary to create initiators that ensure fast cross-linking using a small amount of light. Tromayer et al. proposed the preparation of a two-photon macromolecular initiator, which is based on cyclic dibenzylidene ketones and hyaluronic acid as the initiator core [220]. A biocompatible 2PP type initiator was obtained, which ensured the efficient initiation of the two-photon polymerization reaction and high cell viability, while hyaluronic acid, as the initiator's core, provided it with adequate solubility in an aqueous medium.

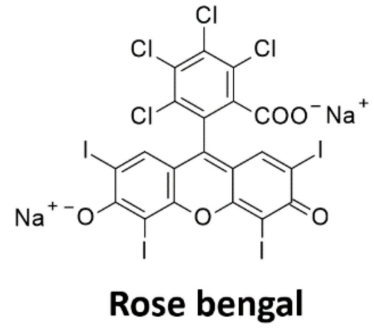

Rose bengal<smiles>O=C1C(I)=C(Oc2c(I)c(I)c(O[N+](=O)[O-])c(I)c2I)C(c2ccccc2C(=O)O)=C1I</smiles>

Erythrosine

Figure 12. Dyes used in the two-photon polymerization process.

The most effective way to increase water solubility is to introduce functional groups, such as quaternary ammonium salts or carboxylic salts, into the chromophore core, which is known for its high two-photon activity. Woo et al. have introduced quaternary ammonium cations for this purpose and the resulting WSPI initiator (1,4-bis $(4-(N, N$-bis $(6-(N, N, N$-trimethylammonium) hexyl)amino) -styryl)-2,5-dimethoxybenzene tetraiodide) has led to the creation of hydrogel materials containing living cells [221,222]. WSPI was also used to obtain protein hydrogels based on thiol and vinyl copolymers [223]. Another group of two-photon initiators includes compounds for which water solubility is guaranteed by the incorporation of carboxylic groups into the structure. This group includes BSEA (2,5-bis-[4-(diethylamino)-benzylidene]-cyclopentanone [224]), P2CK (3,3'-(((1E,1'E) -(2-oxocyclopentane-1,3-diylidene)bis(methanylylidene))bis(4,1-phenylene))bis(methylazanediyl)) dipropanoate) [225,226], and G2CK (sodium 2,2'-(((1E,1'E)-(5-methyl-2-oxocyclohexane-1,3-diylidene) bis(methanylylidene))bis(4,1-phenylene))bis(methylazanediyl))diacetate) (Figure 13).
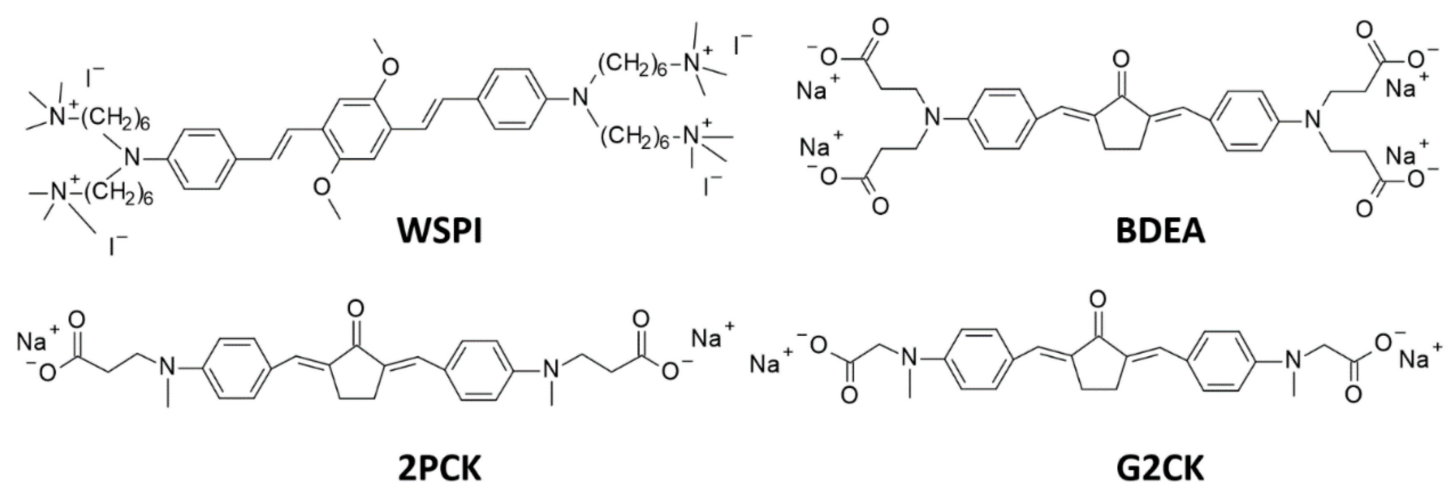

Figure 13. Examples of two-photon initiators used in biomedical applications.

Currently, a promising application of two-photon absorption is two-photon excited photodynamic therapy (TPE-PDT), which, due to its deep penetration, lack of cytotoxicity, and high selectivity, is widely studied and developed. The selection of appropriate photosensitisers is key to effective TPE-PDT. Such a compound must meet the following criteria: hydrophilicity, biocompatibility, and non-toxicity to cells. In order to increase water solubility, the structure of two-photon initiators should be modified, 
such as by introducing carboxylic groups or attaching polyethylene glycol particles to the chain. Yang et al. proposed a series of carboxylate modified benzylidene cyclopentanone (Y1-Y4) as potential sensitizers for use in two-photon therapy [227]. The structures and full names of the initiators are shown in Figure 14. All obtained derivatives were characterised by a broad range of absorption in the visible range, and studies, including EPR, proved that the proposed water-soluble compound can effectively generate radicals. It was shown that the introduction of a larger number of hydrophilic groups into the initiator's structure increases the biological safety of this initiator due to the lower probability of such a molecule being captured by cells [228]. Huang et al. proposed a new series of initiators (T1-T3), which not only initiated the two-photon photopolymerization process effectively but also ensured high cell viability [229]. The structures and full names of the initiators are shown in Figure 14 .
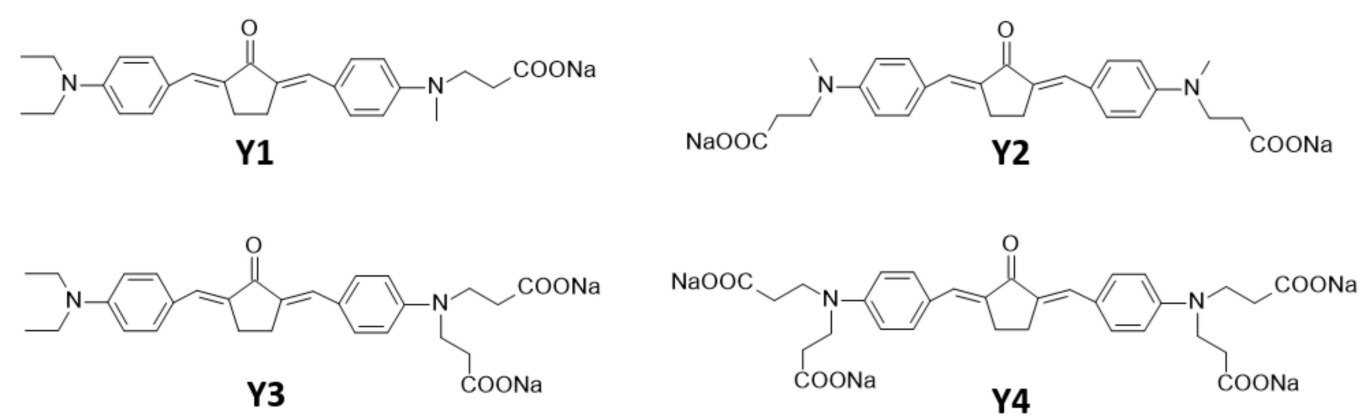<smiles>NC(=O)CCN(CCC(=O)O)c1ccc(C=CC(=O)C=Cc2ccc(N(CCC(N)=O)CCC(=O)O[Na])cc2)cc1</smiles>

T1

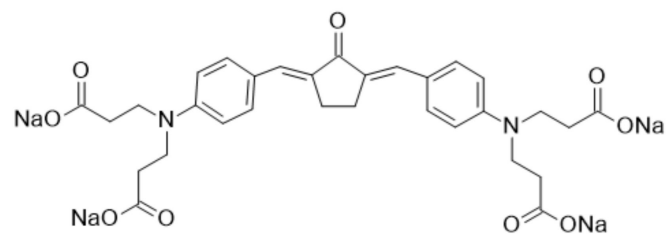

T2<smiles>NC(=O)CCN(CCC(=O)O)c1ccc(C=C2CCC/C(=C\c3ccc(N(CCC(N)=O)CCC(=O)O[Na])cc3)C2=O)cc1</smiles>

T3

Y1: 2-[4-[(2-sodiumcarboxylate-ethyl)(methyl)-amino]-benzyliden]-5-[4-(diethylamino)-benzyliden]-cyclopentanone

Y2: 2-[4-[bis-(2-sodiumcarboxylate-ethyl)-amino]-benzyliden]-5-[4-(diethylamino)-benzyliden]-cyclopentanone

Y3: 2,5-Bis-[4-[(2-sodiumcarboxylate-ethyl)(methyl)-amino]-benzylidene]-cyclopentanone

Y4: 2, 5-Bis-[4-[bis-(2-sodiumcarboxylate-ethyl)-amino]-benzylidene]-cyclopentanone

T1: sodium 3,3',3", $3^{\prime \prime \prime}-((((2-$ oxocyclobutane-1,3-diylidene) bis (methanylylidene)) bis(4,1-phenylene)) bis(azanetriyl)) tetrapropanoate)

T2: sodium 3,3',3", $3^{\prime \prime \prime}-\left(\left(\left(\left(1 \mathrm{E}, 1^{\prime} \mathrm{E}\right)\right.\right.\right.$-(2-oxocyclopentane-1,3-diylidene)bis(methanylylidene))bis(4,1-phenylene))bis(azanetriyl))tetrapropanoate

T3: sodium 3,3', $3^{\prime \prime}, 3^{\prime \prime \prime}$ - $\left(\left(\left(\left(1 \mathrm{E}, 1^{\prime} \mathrm{E}\right)-(2\right.\right.\right.$-oxocyclohexane-1,3-diylidene bis(methanylylidene)) bis(4,1-phenylene)) bis(azanetriyl))tetrapropanoate)

Figure 14. Water-soluble, new initiators containing sodium salt of propionic acid.

\section{Inclusion Complexes of the Host-Guest Type: Photoinitiator-Cyclodextrin}

An interesting way to increase the solubility of hydrophobic initiators in water is through the host-guest chemical interaction. Cyclodextrins are cyclic oligosaccharides built from different amounts of optical active groups, called glucopyranose units (Figure 15 A) [230]. Due to their unique molecular structure, these compounds have the ability to cluster into small molecules with a hydrophobic cavity and hydrophilic outer surface and are, thus, able to form host-guest-type systems [231-233]. Many scientists have, therefore, proposed to increase the solubility of initiators by creating inclusion complexes with different types of cyclodextrin [234]. Balta et al. created thioxanthone photoinitiators using host-guest interactions with $\beta$-cyclodextrin (Figure 15 B) [235]. 
In turn, Temel et al. developed inclusion complexes using benzophenone and methylated $\beta$-cyclodextrin (Figure 15 C) [236]. Similar initiating systems for hydrogel formation were obtained by Ayub through complexation of 2,2-dimethoxy-2-phenyl acetophenone and methylated- $\beta$-cyclodextrin (Figure 15 D) [237]. Such a procedure ensured that a transparent hydrogel with a high degree of cross-linking was obtained. Xing et al. developed a 7-bis(2-(4-pentaneoxyphenyl)-vinyl)anthraquinone and a 2-hydroxypropyl- $\beta$-cyclodextrins (2-HP- $\beta$-CDs) initiating system, which allowed the production of hydrogel materials with the use of two-photon polymerization [238].

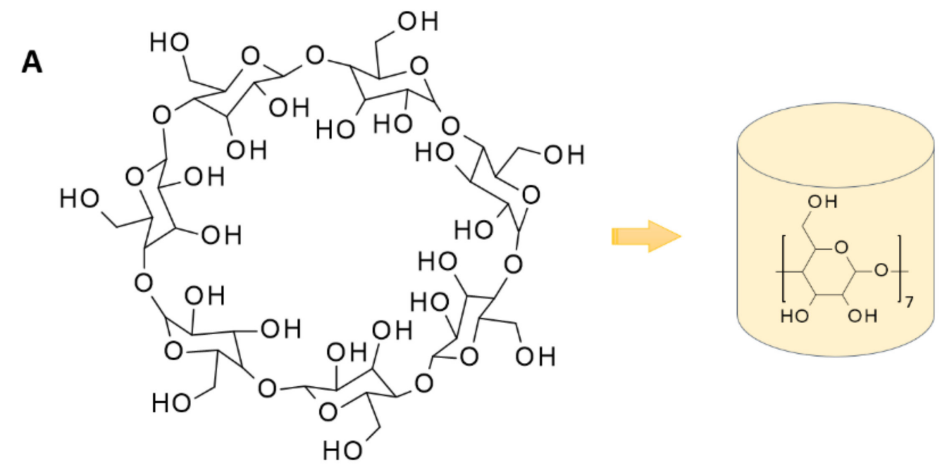

B

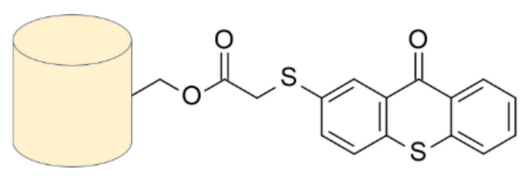

C

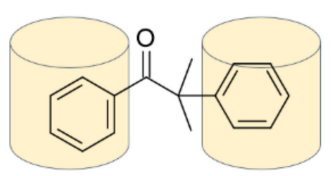

D

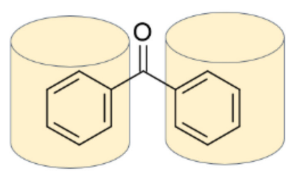

Figure 15. $\beta$-cyclodextrin structure and inclusion complexes of the host-guest type with photoinitiators; (A): $\beta$-cyclodextrin, (B): thioxanthone and $\beta$-cyclodextrin, $(\mathbf{C})$ : benzophenone and $\beta$-cyclodextrin, (D): 2,2-dimethoxy-2-phenyl acetophenone and $\beta$-cyclodextrin.

\section{Multi-Component Water-Soluble Photo Initiating Systems}

Multi-component initiating systems are very popular in the processes of photo induced polymerization reactions, mainly due to the fact that their absorption characteristics can be compatible with the emission characteristics of the light sources, such as UV-A-LEDs and Vis-LEDs. Such systems are also used in biomedical applications. Zuo et al. proposed to use of commercial fluorescent brighteners (styrene-based, coumarin-based, and 2,5-bis(benzoxazolyl)thiophene-based derivatives) together with commercially available iodine salt-diphenyliodonium hexafluorophosphate-to create hydrogel materials [239]. Coumarin derivatives together with water-soluble N-methyldiethanolamine acted as a multi-component initiating system to create a hydrogel with (hydroxyethyl)methacrylate [240]. The same amine co-initiator was used to obtain hydrogel through an amine-diketopyrrolopyrrole (DKPP) derivative system [241,242]. The structures of widely used additives in multi-component initiating systems for biomedical applications are shown in Figure 16.
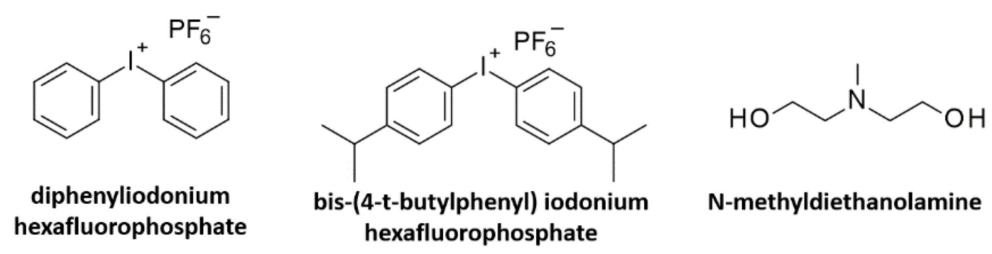

Figure 16. The structures of widely used additives in multi-component initiating systems for biomedical applications. 
Table 2. Summary of the main water-soluble initiators used in biomedical applications, their basic properties, and photo induced cleavage of photoinitiators.

\begin{tabular}{|c|c|c|c|c|c|c|}
\hline $\begin{array}{l}\text { Type of } \\
\text { Initiator }\end{array}$ & $\begin{array}{l}\text { Name of } \\
\text { Initiator }\end{array}$ & $\begin{array}{l}\text { Structure, Together with a Simplified Scheme } \\
\text { of Photoinduced Cleavage of Photoinitiator }\end{array}$ & $\begin{array}{c}\text { Maximum } \\
\text { Absorbance / } \\
\text { Source of } \\
\text { Irradiation } \\
\end{array}$ & Key Strengths & Key Drawbacks & Ref. \\
\hline Type I & $\begin{array}{l}\text { Irgacure } \\
2959\end{array}$ & 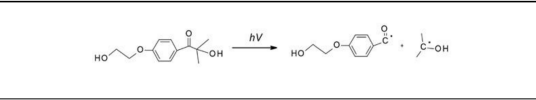 & $\begin{array}{l}276 \mathrm{~nm} / \\
365 \mathrm{~nm}\end{array}$ & $\begin{array}{l}\text { High initiation rate, low } \\
\text { cytotoxicity, and immune- } \\
\text { genicity }\end{array}$ & $\begin{array}{l}\text { Low initiation efficiency, need } \\
\text { for UV light sources, low water } \\
\text { solubility (<5 w. } \%)\end{array}$ & [104] \\
\hline Type I & TPO & & $\begin{array}{c}267,298, \\
\text { and } 380 \mathrm{~nm}\end{array}$ & $\begin{array}{l}\text { Cleaves into highly reactive } \\
\text { radicals, good thermal stability }\end{array}$ & Poor water solubility & [146] \\
\hline Type I & LAP & & $\begin{array}{c}375 \mathrm{~nm} / \\
(320-390 \mathrm{~nm}) \\
405 \mathrm{~nm}\end{array}$ & $\begin{array}{l}\text { Good water solubility, } \\
\text { possibility of using UV and } \\
\text { visible light sources }\end{array}$ & $\begin{array}{l}\text { Low initiation efficiency, } \\
\text { especially when exposed to } \\
\text { light from the visible range }\end{array}$ & $\begin{array}{l}{[138],} \\
{[142]}\end{array}$ \\
\hline Type I & BAPO-OLi & 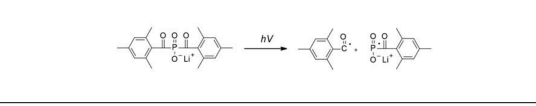 & $\begin{array}{c}375 \mathrm{~nm} / \\
(320-420 \mathrm{~nm})\end{array}$ & $\begin{array}{c}\text { Good water solubility } \\
\qquad 54 \mathrm{~g} / 1\end{array}$ & $\begin{array}{c}\text { Very low extinction coefficient } \\
\text { in the range above } \\
400 \mathrm{~nm}\end{array}$ & [142-144] \\
\hline Type I & VA-086 & & $\begin{array}{c}365 \mathrm{~nm} / \\
(365-385 \mathrm{~nm})\end{array}$ & $\begin{array}{l}\text { Low toxicity, providing } 90 \% \\
\text { cell survival, high initiation } \\
\text { rate, good water solubility }\end{array}$ & $\begin{array}{l}\text { Released nitrogen causes } \\
\text { bubble formation }\end{array}$ & $\begin{array}{l}{[97],} \\
{[150-152]}\end{array}$ \\
\hline Type II & Eosin-Y & & $\begin{array}{c}528 \mathrm{~nm} / \\
(400-800 \mathrm{~nm})\end{array}$ & $\begin{array}{l}\text { Good water solubility, low } \\
\text { cytotoxicity, wide range of } \\
\text { absorbance, possibility to use } \\
\text { different light sources in visible } \\
\text { range, possibility to use low } \\
\text { light powers }\end{array}$ & $\begin{array}{c}\text { A second ingredient is needed } \\
\text { for high initiation efficiency - } \\
\text { the co-initiator }\end{array}$ & $\begin{array}{c}{[158],} \\
{[159,243]}\end{array}$ \\
\hline Type II & $\begin{array}{l}\text { Camphor- } \\
\text { quinone }\end{array}$ & & $\begin{array}{c}444 \mathrm{~nm} / \\
(400-500 \mathrm{~nm})\end{array}$ & $\begin{array}{l}\text { Wide absorption range based } \\
\text { on the visible range }\end{array}$ & $\begin{array}{l}\text { Modification needed to } \\
\text { increase solubility in water, } \\
\text { strongly yellow after reaction }\end{array}$ & $\begin{array}{l}{[105],} \\
{[186]}\end{array}$ \\
\hline Type II & Riboflavin & & $\begin{array}{c}223,267,373 \text { and } \\
444 \mathrm{~nm} / \\
(300-500 \mathrm{~nm})\end{array}$ & $\begin{array}{l}\text { Excellent water solubility, wide } \\
\text { absorption range, also in the } \\
\text { visible area, non-toxic, } \\
\text { beneficial to cells }\end{array}$ & $\begin{array}{l}\text { Possibility of creating reactive } \\
\text { oxygen species }\end{array}$ & $\begin{array}{l}{[167],} \\
{[177]}\end{array}$ \\
\hline $2 \mathrm{PP}$ & WSPI & & \multirow{3}{*}{$\begin{array}{l}\text { source of } \\
\text { irradiation: laser- } \\
800 \mathrm{~nm}\end{array}$} & \multirow{3}{*}{$\begin{array}{l}\text { very good water solubility, } \\
\text { excellent optical sensitivity, } \\
\text { and resolution, no toxicity }\end{array}$} & \multirow{3}{*}{$\begin{array}{l}\text { significant limitations of speed } \\
\text { fabrication }\end{array}$} & $\begin{array}{l}{[207]} \\
{[221]} \\
{[244]}\end{array}$ \\
\hline $2 \mathrm{PP}$ & BDEA & & & & & [224] \\
\hline $2 \mathrm{PP}$ & P2CK & 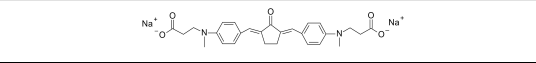 & & & & [225] \\
\hline
\end{tabular}




\section{Fields of Application for Water-Soluble Photoinitiators}

In recent years, polymeric hydrogels have garnered plenty of interest in terms of their potential application due to the fact that their structural and biochemical properties are similar to those of the extracellular matrix (ECM) of most tissues [229]. Moreover, they show high porosity, which ensures high permeability to nutrients, oxygen, and metabolic products. The properties of these materials can also be adapted to the mechanical properties of soft tissues. Hydrogels for tissue engineering should be hydrophilic in order to promote cell adhesion, while the three-dimensional structure of these scaffolds should be porous to facilitate cell and nutrient diffusion $[184,243]$. Hydrogels are produced by cross-linking hydrophilic monomers or oligomers. Although hydrogels can be formed by conventional polymerization methods, e.g., thermally, using thermal initiators or initiators acting on the principle of redox reaction, polymerization under the influence of light is of the greatest interest. Compared to other methods, photopolymerization has many advantages: it is a very fast reaction (lasting from a few seconds to a few minutes) and allows spatial control over the resulting hydrogel, which permits the creation of various shapes that fit into the tissue structure. Currently, photo induced systems for the production of hydrogels include: radical polymerization under the influence of ultraviolet (UV) and visible (Vis) lights in water, or two-photon photopolymerization and thiol-en photopolymerization [245-247]. Hydrogels with an interpenetrating polymer network structure are also becoming increasingly more popular [248]. Photocured hydrogel materials are used in numerous applications, e.g., biosensing [249,250], encapsulation [18,251,252], drug delivery systems [253,254], scaffolding for the cell culture $[255,256]$, in situ polymerization $[257,258]$, and even direct polymerization in living cells $[259,260]$. All techniques of 3D printing are highly developed [261,262], including laser writing [263,264], inkjet bioprinting [265], and stereolithography [202,266,267]. Other applications include the production of various materials, including scaffolds [268] and layered hydrogels using surface photopolymerization [269].

\section{Conclusions}

In conclusion, interest in water-soluble photoinitiators has been ongoing for almost half a century. Significant developments in medicine, including nanomedicine [270], promote the advancement of photopolymerization processes, as well as the necessary initiating systems in the near future. The currently available modern technologies of nanomedicine, such as targeted drug therapy, modern analysis, and diagnostics of diseases, and the production of materials for cell or tissue culture, will require new and increasingly improved initiators that will meet all the criteria for the introduction of materials into the medical market.

The development of water-soluble initiating systems is likely to take two directions. First, it will be based on the synthesis of completely new Type I or Type II photoinitiators with a wide absorption range reaching the visible range and, additionally, fulfilling a number of other requirements, such as lack of cytotoxicity, biocompatibility, and high initiation efficiency. Such photoinitiators can be applied, among others, in the processes of in situ polymerization, in targeted drug delivery, and in cell encapsulation, which may positively affect the treatment of some diseases, such as type I diabetes by the encapsulation of islets of Langerhans.

The second direction of development is the study of two-photon photoinitiators (2PP), which will allow the effective production of hydrogel materials containing living cells with the use of 3D laser printing with extremely high resolution. The constant challenge is to obtain initiators with a simple and inexpensive synthesis path in which the scale can be easily transferred to the industry.

This literature review has presented previous achievements in the field of water-soluble initiators in biomedical applications and has pointed at likely development paths and potential applications of photopolymerization processes. 
Author Contributions: Conceptualization, formal analysis, data curation, writing-original draft preparation, visualization, W.T.; Conceptualization, writing — review and editing, J.O. Both authors have read and agreed to the published version of the manuscript.

Funding: The project: “WAY TO EXCELLENCE - a comprehensive university support program" implemented under the Operational Program Knowledge Education Development 2014-2020 co-financed by the European Social Fund WND-POWR.03.05.00-00-Z214/18 funded this publication.

Conflicts of Interest: The authors declare no conflict of interest.

\section{References}

1. Yagci, Y.; Jockusch, S.; Turro, N.J. Photoinitiated polymerization: Advances, challenges, and opportunities. Macromolecules 2010, 43, 6245-6260. [CrossRef]

2. Chatani, S.; Kloxin, C.J.; Bowman, C.N. The power of light in polymer science: Photochemical processes to manipulate polymer formation, structure, and properties. Polym. Chem. 2014, 5, 2187-2201. [CrossRef]

3. Kamińska, I.; Ortyl, J.; Popielarz, R. Mechanism of interaction of coumarin-based fluorescent molecular probes with polymerizing medium during free radical polymerization of a monomer. Polym. Test. 2016, 55, 310-317. [CrossRef]

4. Nowak, D.; Ortyl, J.; Kamińska-Borek, I.; Kukuła, K.; Topa, M.; Popielarz, R. Photopolymerization of hybrid monomers: Part I: Comparison of the performance of selected photoinitiators in cationic and free-radical polymerization of hybrid monomers. Polym. Test. 2017, 64, 313-320. [CrossRef]

5. Nowak, D.; Ortyl, J.; Kamińska-Borek, I.; Kukuła, K.; Topa, M.; Popielarz, R. Photopolymerization of hybrid monomers, Part II: Determination of relative quantum efficiency of selected photoinitiators in cationic and free-radical polymerization of hybrid monomers. Polym. Test. 2018, 67, 144-150. [CrossRef]

6. Kostrzewska, K.; Ortyl, J.; Dobosz, R.; Kabatc, J. Squarylium dye and onium salts as highly sensitive photoradical generators for blue light. Polym. Chem. 2017, 8, 3464-3474. [CrossRef]

7. Glöckner, P.; Struck, S.; Jung, T.; Studer, K. Radiation Curing: Coatings and Printing Inks; Technical Basics, Applications and Trouble Shooting; Vincentz Network: Hannover, Germany, 2008; ISBN 9783866309074.

8. Green, W.A. Industrial Photoinitiators-A technical Guide; CRC Press: Boca Raton, FL, USA, 2010; ISBN 9781439827451.

9. Czech, Z.; Kowalczyk, A.; Ortyl, J.; Swiderska, J. Acrylic pressure-sensitive adhesives containing SiO2 nanoparticles. Polish J. Chem. Technol. 2013, 15, 12-14. [CrossRef]

10. Chen, R.T.; Zhou, C.; Zhao, C.; Lee, R. Photopolymer-based waveguide holograms for optoelectronic interconnect applications. In Proceedings of the Polymers in Optics: Physics, Chemistry, and Applications: A Critical Review; SPIE: Bellingham, WA, USA, 1996; Volume 10285, p. 1028504.

11. Liska, R.; Schuster, M.; Inführ, R.; Turecek, C.; Fritscher, C.; Seidl, B.; Schmidt, V.; Kuna, L.; Haase, A.; Varga, F.; et al. Photopolymers for rapid prototyping. J. Coatings Technol. Res. 2007, 4, 505-510. [CrossRef]

12. Bagheri, A.; Jin, J. Photopolymerization in 3D Printing. ACS Appl. Polym. Mater. 2019, 1, 593-611. [CrossRef]

13. Tomal; Pilch; Chachaj-Brekiesz; Ortyl Development of New High-Performance Biphenyl and Terphenyl Derivatives as Versatile Photoredox Photoinitiating Systems and Their Applications in 3D Printing Photopolymerization Processes. Catalysts 2019, 9, 827. [CrossRef]

14. Hola, E.; Topa, M.; Chachaj-Brekiesz, A.; Pilch, M.; Fiedor, P.; Galek, M.; Ortyl, J. New, highly versatile bimolecular photoinitiating systems for free-radical, cationic and thiol-ene photopolymerization processes under low light intensity UV and visible LEDs for 3D printing application. RSC Adv. 2020, 10, 7509-7522. [CrossRef]

15. Fiedor, P.; Pilch, M.; Szymaszek, P.; Chachaj-Brekiesz, A.; Galek, M.; Ortyl, J. Photochemical Study of a New Bimolecular Photoinitiating System for Vat Photopolymerization 3D Printing Techniques under Visible Light. Catalysts 2020, 10, 284. [CrossRef]

16. Zhang, J.; Xiao, P. 3D printing of photopolymers. Polym. Chem. 2018, 9, 1530-1540. [CrossRef]

17. Layani, M.; Wang, X.; Magdassi, S. Novel Materials for 3D Printing by Photopolymerization. Adv. Mater. 2018, 30, e1706344. [CrossRef]

18. Baroli, B. Photopolymerization of biomaterials: Issues and potentialities in drug delivery, tissue engineering, and cell encapsulation applications. J. Chem. Technol. Biotechnol. 2006, 81, 491-499. [CrossRef] 
19. Fisher, J.P.; Dean, D.; Engel, P.S.; Mikos, A.G. Photoinitiated Polymerization of Biomaterials. Annu. Rev. Mater. Res. 2001, 31, 171-181. [CrossRef]

20. Stansbury, J.W. Curing dental resins and composites by photopolymerization. J. Esthet. Restor. Dent. 2000, 12, 300-308. [CrossRef]

21. Khosroshahi, M.E.; Atai, M.; Nourbakhsh, M.S. Photopolymerization of dental resin as restorative material using an argon laser. Lasers Med. Sci. 2008, 23, 399-406. [CrossRef]

22. Maffezzoli, A.; Pietra, A.D.; Rengo, S.; Nicolais, L.; Valletta, G. Photopolymerization of dental composite matrices. Biomaterials 1994, 15, 1221-1228. [CrossRef]

23. Dickens, S.H.; Stansbury, J.W.; Choi, K.M.; Floyd, C.J.E. Photopolymerization kinetics of methacrylate dental resins. Macromolecules 2003, 36, 6043-6053. [CrossRef]

24. Peppas, N.A.; Hilt, J.Z.; Khademhosseini, A.; Langer, R. Hydrogels in Biology and Medicine: From Molecular Principles to Bionanotechnology. Adv. Mater. 2006, 18, 1345-1360. [CrossRef]

25. Ifkovits, J.L.; Burdick, J.A. Review: Photopolymerizable and degradable biomaterials for tissue engineering applications. Tissue Eng. 2007, 13, 2369-2385. [CrossRef]

26. Censi, R.; Schuurman, W.; Malda, J.; di Dato, G.; Burgisser, P.E.; Dhert, W.J.A.; van Nostrum, C.F.; di Martino, P.; Vermonden, T.; Hennink, W.E. A Printable Photopolymerizable Thermosensitive p(HPMAm-lactate)-PEG Hydrogel for Tissue Engineering. Adv. Funct. Mater. 2011, 21, 1833-1842. [CrossRef]

27. Gonen-Wadmany, M.; Oss-Ronen, L.; Seliktar, D. Protein-polymer conjugates for forming photopolymerizable biomimetic hydrogels for tissue engineering. Biomaterials 2007, 28, 3876-3886. [CrossRef]

28. Baier Leach, J.; Bivens, K.A.; Patrick, C.W., Jr.; Schmidt, C.E. Photocrosslinked hyaluronic acid hydrogels: Natural, biodegradable tissue engineering scaffolds. Biotechnol. Bioeng. 2003, 82, 578-589. [CrossRef]

29. Quick, D.J.; Anseth, K.S. Gene Delivery in Tissue Engineering: A Photopolymer Platform to Coencapsulate Cells and Plasmid DNA. Pharm. Res. 2003, 20, 1730-1737. [CrossRef]

30. Herr, A.E.; Singh, A.K. Photopolymerized cross-linked polycrylamide gels for on-chip protein sizing. Anal. Chem. 2004, 76, 4727-4733. [CrossRef]

31. Cao, Q.; Heil, T.; Kumru, B.; Antonietti, M.; Schmidt, B.V.K.J. Visible-light induced emulsion photopolymerization with carbon nitride as a stabilizer and photoinitiator. Polym. Chem. 2019, 10, 5315-5323. [CrossRef]

32. Pereira, R.F.; Bártolo, P.J. Photopolymerizable hydrogels in regenerative medicine and drug delivery. In Hot Topics in Biomaterials; Future Medicine Ltd.: London, UK, 2014; pp. 6-28. ISBN 9781909453708.

33. Censi, R.; Vermonden, T.; van Steenbergen, M.J.; Deschout, H.; Braeckmans, K.; De Smedt, S.C.; van Nostrum, C.F.; di Martino, P.; Hennink, W.E. Photopolymerized thermosensitive hydrogels for tailorable diffusion-controlled protein delivery. J. Control. Release 2009, 140, 230-236. [CrossRef]

34. Elisseeff, J.; Anseth, K.; Sims, D.; Mcintosh, W.; Randolph, M.; Langer, R. Transdermal photopolymerization for minimally invasive implantation. Proc. Natl. Acad. Sci. USA 1999, 96, 3104-3107. [CrossRef]

35. Lu, S.; Anseth, K.S. Photopolymerization of multilaminated poly(HEMA) hydrogels for controlled release. J. Control. Release 1999, 57, 291-300. [CrossRef]

36. Ye, Q.; Park, J.; Topp, E.; Spencer, P. Effect of Photo-Initiators on the In Vitro Performance of a Dentin Adhesive Exposed to Simulated Oral Environment. Dent. Mater. 2009, 25, 452. [CrossRef]

37. Kunio, I.; Takeshi, E. A review of the development of radical photopolymerization initiators used for designing light-curing dental adhesives and resin composites. Dent. Mater. J. 2010, 29, 481-501.

38. Salgado, V.E.; Cavassoni, D.; Gonçalves, A.P.R.; Pfeifer, C.; Moraes, R.R.; Schneider, L.F. Photoinitiator system and water effects on $\mathrm{C}=\mathrm{C}$ conversion and solubility of experimental etch-and-rinse dental adhesives. Int. J. Adhes. Adhes. 2017, 72, 6-9. [CrossRef]

39. Albuquerque, P.P.A.C.; Moreira, A.D.L.; Moraes, R.R.; Cavalcante, L.M.; Schneider, L.F.J. Color stability, conversion, water sorption and solubility of dental composites formulated with different photoinitiator systems. J. Dent. 2013, 41, e67-e72. [CrossRef]

40. Clapper, J.D.; Skeie, J.M.; Mullins, R.F.; Guymon, C.A. Development and characterization of photopolymerizable biodegradable materials from PEG-PLA-PEG block macromonomers. Polymer 2007, 48, 6554-6564. [CrossRef]

41. Wang, K.; Lu, J.; Yin, R.; Chen, L.; Du, S.; Jiang, Y.; Yu, Q. Preparation and properties of cyclic acetal based biodegradable gel by thiol-ene photopolymerization. Mater. Sci. Eng. C 2013, 33, 1261-1266. [CrossRef] 
42. Kim, B.S.; Hrkach, J.S.; Langer, R. Biodegradable photo-crosslinked poly(ether-ester) networks for lubricious coatings. Biomaterials 2000, 21, 259-265. [CrossRef]

43. Claeyssens, F.; Hasan, E.A.; Gaidukeviciute, A.; Achilleos, D.S.; Ranella, A.; Reinhardt, C.; Ovsianikov, A.; Shizhou, X.; Fotakis, C.; Vamvakaki, M.; et al. Three-dimensional biodegradable structures fabricated by two-photon polymerization. Langmuir 2009, 25, 3219-3223. [CrossRef]

44. Hiemstra, C.; Zhou, W.; Zhong, Z.; Wouters, M.; Feijen, J. Rapidly in situ forming biodegradable robust hydrogels by combining stereocomplexation and photopolymerization. J. Am. Chem. Soc. 2007, 129, 9918-9926. [CrossRef]

45. Elisseeff, J.; McIntosh, W.; Fu, K.; Blunk, T.; Langer, R. Controlled-release of IGF-I and TGF- $\beta 1$ in a photopolymerizing hydrogel for cartilage tissue engineering. J. Orthop. Res. 2001, 19, 1098-1104. [CrossRef]

46. Mann, B.K.; Gobin, A.S.; Tsai, A.T.; Schmedlen, R.H.; West, J.L. Smooth muscle cell growth in photopolymerized hydrogels with cell adhesive and proteolytically degradable domains: Synthetic ECM analogs for tissue engineering. Biomaterials 2001, 22, 3045-3051. [CrossRef]

47. Bryant, S.J.; Nicodemus, G.D.; Villanueva, I. Designing 3D photopolymer hydrogels to regulate biomechanical cues and tissue growth for cartilage tissue engineering. Pharm. Res. 2008, 25, 2379-2386. [CrossRef] [PubMed]

48. Shapira-Schweitzer, K.; Habib, M.; Gepstein, L.; Seliktar, D. A photopolymerizable hydrogel for 3-D culture of human embryonic stem cell-derived cardiomyocytes and rat neonatal cardiac cells. J. Mol. Cell. Cardiol. 2009, 46, 213-224. [CrossRef] [PubMed]

49. Wang, H.; Feng, Y.; An, B.; Zhang, W.; Sun, M.; Fang, Z.; Yuan, W.; Khan, M. Fabrication of PU/PEGMA crosslinked hybrid scaffolds by in situ UV photopolymerization favoring human endothelial cells growth for vascular tissue engineering. J. Mater. Sci. Mater. Med. 2012, 23, 1499-1510. [CrossRef] [PubMed]

50. Skardal, A.; Zhang, J.; McCoard, L.; Xu, X.; Oottamasathien, S.; Prestwich, G.D. Photocrosslinkable hyaluronan-gelatin hydrogels for two-step bioprinting. Tissue Eng. Part A 2010, 16, 2675-2685. [CrossRef]

51. Tytgat, L.; Baudis, S.; Ottevaere, H.; Liska, R.; Thienpont, H.; Dubruel, P.; Van Vlierberghe, S. Photopolymerizable Materials for Cell Encapsulation. In 3D Printing and Biofabrication; Springer International Publishing: Cham, Switzerland, 2017; pp. 1-43.

52. Younes, H.M. Photopolymerization of Polymeric Composites in Drug Delivery, Tissue Engineering, and Other Biomedical Applications. In Lecture Notes in Bioengineering; Springer International Publishing: Cham, Switzerland, 2019; pp. 271-297.

53. Zhong, C.; Wu, J.; Reinhart-King, C.A.; Chu, C.C. Synthesis, characterization and cytotoxicity of photo-crosslinked maleic chitosan-polyethylene glycol diacrylate hybrid hydrogels. Acta Biomater. 2010, 6, 3908-3918. [CrossRef]

54. Zhou, D.; Ito, Y. Visible light-curable polymers for biomedical applications. Sci. China Chem. 2014, 57, 510-521. [CrossRef]

55. West, J.L.; Hubbell, J.A. Comparison of covalently and physically cross-linked polyethylene glycol-based hydrogels for the prevention of postoperative adhesions in a rat model. Biomaterials 1995, 16, 1153-1156. [CrossRef]

56. De Paepe, I.; Declercq, H.; Cornelissen, M.; Schacht, E. Novel hydrogels based on methacrylate-modified agarose. Polym. Int. 2002, 51, 867-870. [CrossRef]

57. Van Nieuwenhove, I.; Van Vlierberghe, S.; Salamon, A.; Peters, K.; Thienpont, H.; Dubruel, P. Photo-crosslinkable biopolymers targeting stem cell adhesion and proliferation: the case study of gelatin and starch-based IPNs. J. Mater. Sci. Mater. Med. 2015, 26, 1-8. [CrossRef] [PubMed]

58. Fedorovich, N.E.; Oudshoorn, M.H.; van Geemen, D.; Hennink, W.E.; Alblas, J.; Dhert, W.J.A. The effect of photopolymerization on stem cells embedded in hydrogels. Biomaterials 2009, 30, 344-353. [CrossRef] [PubMed]

59. Moad, G.; Solomon, D.H. The Chemistry of Radical Polymerization; Elsevier: Oxford, UK, 2005; ISBN 9780080442884

60. Hyun, J.; Chilkoti, A. Surface-initiated free radical polymerization of polystyrene micropatterns on a self-assembled monolayer on gold. Macromolecules 2001, 34, 5644-5652. [CrossRef]

61. Heller, C.; Schwentenwein, M.; Russmüller, G.; Koch, T.; Moser, D.; Schopper, C.; Varga, F.; Stampfl, J.; Liska, R. Vinylcarbonates and vinylcarbamates: Biocompatible monomers for radical photopolymerization. J. Polym. Sci. Part A Polym. Chem. 2011, 49, 650-661. [CrossRef] 
62. Uygun, M.; Kahveci, M.U.; Odaci, D.; Timur, S.; Yagci, Y. Antibacterial Acrylamide Hydrogels Containing Silver Nanoparticles by Simultaneous Photoinduced Free Radical Polymerization and Electron Transfer Processes. Macromol. Chem. Phys. 2009, 210, 1867-1875. [CrossRef]

63. Ward, J.H.; Peppas, N.A. Preparation of controlled release systems by free-radical UV polymerizations in the presence of a drug. J. Control. Release 2001, 71, 183-192. [CrossRef]

64. Eguiburu, J.L.; Fernandez-Berridi, M.J.; San Román, J. Graft copolymers for biomedical applications prepared by free radical polymerization of poly(L-lactide) macromonomers with vinyl and acrylic monomers. Polymer 1996, 37, 3615-3622. [CrossRef]

65. Ortyl, J. Chapter 3: Cationic Photoinitiators. In RSC Polymer Chemistry Series; Royal Society of Chemistry: Cambridge, UK, 2018.

66. Ficek, B.A. The potential of cationic photopolymerization's long lived active centers. Ph.D. Thesis, University of Iowa, Iowa City, IA, USA, 2008.

67. Ortyl, J.; Wilamowski, J.; Milart, P.; Galek, M.; Popielarz, R. Relative sensitization efficiency of fluorescent probes/sensitizers for monitoring and acceleration of cationic photopolymerization of monomers. Polym. Test. 2015, 48, 151-159. [CrossRef]

68. Ortyl, J.; Milart, P.; Popielarz, R. Applicability of aminophthalimide probes for monitoring and acceleration of cationic photopolymerization of epoxides. Polym. Test. 2013, 32, 708-715. [CrossRef]

69. Nguyen, K.T.; West, J.L. Photopolymerizable hydrogels for tissue engineering applications. Biomaterials 2002, 23, 4307-4314. [CrossRef]

70. Huang, R.; Ficek, B.A.; Glover, S.O.; Scranton, A.B. Effect of Water in Cationic Photopolymerizations: Reversible Inhibition. Tech. Pap. 2007, 30-35.

71. Ranaweera, R.A.A.U.; Schuman, T.P.; Wang, R.; Miller, B.D.; Kilway, K.V. Effect of moisture on cationic polymerization of silicone epoxy monomers. J. Appl. Polym. Sci. 2015, 132, 41831. [CrossRef]

72. Barker, P.; Guthrie, J.T.; Davis, M.J.; Godfrey, A.A.; Green, P.N. Sensitized photoinitiated grafting of N-vinyl-2-prrolidone (NVP) to woolen substrates. J. Appl. Polym. Sci. 1981, 26, 521-527. [CrossRef]

73. Ferreira, P.; Coelho, J.F.J.; Almeida, J.F.; Gill, M.H. Photocrosslinkable Polymers for Biomedical Applications. In Biomedical Engineering — Frontiers and Challenges; InTech: Rijeka, Croatia, 2011.

74. Dumur, F. Recent advances on carbazole-based photoinitiators of polymerization. Eur. Polym. J. 2020, 125, 109503. [CrossRef]

75. Zhou, J.; Allonas, X.; Ibrahim, A.; Liu, X. Progress in the development of polymeric and multifunctional photoinitiators. Prog. Polym. Sci. 2019, 99, 101165. [CrossRef]

76. Lougnot, D.J.; Turck, C.; Fouassier, J.P. Water-Soluble Polymerization Initiators Based on the Thioxanthone Structure: A Spectroscopic and Laser Photolysis Study. Macromolecules 1989, 22, 108-116. [CrossRef]

77. Allen, N.S.; Howells, E.M.; Lam, E.; Catalina, F.; Green, P.N.; Green, W.A.; Chen, W. Photopolymerisation and flash photolysis of a water soluble benzophenone photoinitiator: Influence of tertiary amine. Eur. Polym. J. 1988, 24, 591-593. [CrossRef]

78. Eibel, A.; Fast, D.E.; Gescheidt, G. Choosing the ideal photoinitiator for free radical photopolymerizations: Predictions based on simulations using established data. Polym. Chem. 2018, 9, 5107-5115. [CrossRef]

79. Ciuciu, A.I.; Cywiński, P.J. Two-photon polymerization of hydrogels-versatile solutions to fabricate well-defined 3D structures. RSC Adv. 2014, 4, 45504-45516. [CrossRef]

80. Liao, W.; Xu, C.; Wu, X.; Liao, Q.; Xiong, Y.; Li, Z.; Tang, H. Photobleachable cinnamoyl dyes for radical visible photoinitiators. Dye. Pigment. 2020, 108350. [CrossRef]

81. Allushi, A.; Kutahya, C.; Aydogan, C.; Kreutzer, J.; Yilmaz, G.; Yagci, Y. Conventional Type II photoinitiators as activators for photoinduced metal-free atom transfer radical polymerization. Polym. Chem. 2017, 8, 1972-1977. [CrossRef]

82. Dadashi-Silab, S.; Aydogan, C.; Yagci, Y. Shining a light on an adaptable photoinitiator: advances in photopolymerizations initiated by thioxanthones. Polym. Chem. 2015, 6, 6595-6615. [CrossRef]

83. Weiß, T.; Hildebrand, G.; Schade, R.; Liefeith, K. Two-photon polymerization for microfabrication of three-dimensional scaffolds for tissue engineering application. Eng. Life Sci. 2009, 9, 384-390.

84. Tromayer, M.; Dobos, A.; Gruber, P.; Ajami, A.; Dedic, R.; Ovsianikov, A.; Liska, R. A biocompatible diazosulfonate initiator for direct encapsulation of human stem cells: Via two-photon polymerization. Polym. Chem. 2018, 9, 3108-3117. [CrossRef] 
85. Woo, H.Y.; Hong, J.W.; Liu, B.; Mikhailovsky, A.; Korystov, D.; Bazan, G.C. Water-soluble [2.2]paracyclophane chromophores with large two-photon action cross sections. J. Am. Chem. Soc. 2005, 127, 820-821. [CrossRef] [PubMed]

86. Reinhardt, B.A.; Brott, L.L.; Clarson, S.J.; Dillard, A.G.; Bhatt, J.C.; Kannan, R.; Yuan, L.; He, G.S.; Prasad, P.N. Highly Active Two-Photon Dyes: Design, Synthesis, and Characterization toward Application. Chem. Mater. 1998, 10, 1863-1874. [CrossRef]

87. Wrzyszczyński, A. Two-photon initiators of polymerization. Polimery 2010, 55, 167-171. [CrossRef]

88. Demet, K.B.; Temel, G.; Aydin, M.; Arsu, N. Thioxanthone based water-soluble photoinitiators for acrylamide photopolymerization. Eur. Polym. J. 2010, 46, 1374-1379.

89. Liska, R. Photoinitiators with functional groups. V. New water-soluble photoinitiators containing carbohydrate residues and copolymerizable derivatives thereof. J. Polym. Sci. Part A Polym. Chem. 2002, 40, 1504-1518. [CrossRef]

90. Temel, G.; Arsu, N. One-pot synthesis of water-soluble polymeric photoinitiator via thioxanthonation and sulfonation process. J. Photochem. Photobiol. A Chem. 2009, 202, 63-66. [CrossRef]

91. Guo, R.; Gao, Y.; Wu, M.; Wang, H. Aliphatic ketones and aldehydes as water-soluble photoinitiators for the photopolymerization of methacrylic acid. Polymer 2013, 54, 4940-4947. [CrossRef]

92. Liang, Q.; Zhang, L.; Xiong, Y.; Wu, Q.; Tang, H. A facile method to prepare a polyethylene glycol modified polysilane as a waterborne photoinitiator. J. Photochem. Photobiol. A Chem. 2015, 299, 9-17. [CrossRef]

93. Lougnot, D.J.; Fouassier, J.P. Comparative reactivity of water soluble photoinitiators as viewed in terms of excited states processes. J. Polym. Sci. Part A Polym. Chem. 1988, 26, 1021-1033. [CrossRef]

94. Fouassier, J.-P.; Burr, D.; Wieder, F. Water-soluble photoinitiators: Primary processes in hydroxy alkyl phenyl ketones. J. Polym. Sci. Part A Polym. Chem. 1991, 29, 1319-1327. [CrossRef]

95. Knaus, S.; Gruber, H.F. Photoinitiators with functional groups. III. Water-soluble photoinitiators containing carbohydrate residues. J. Polym. Sci. Part A Polym. Chem. 1995, 33, 929-939. [CrossRef]

96. Rouillard, A.D.; Berglund, C.M.; Lee, J.Y.; Polacheck, W.J.; Tsui, Y.; Bonassar, L.J.; Kirby, B.J. Methods for photocrosslinking alginate hydrogel scaffolds with high cell viability. Tissue Eng. Part C Methods 2011, 17, 173-179. [CrossRef]

97. Ma, Z.; Niu, X.; Xu, Z.; Guo, J. Synthesis of novel macrophotoinitiator for the photopolymerization of acrylate. J. Appl. Polym. Sci. 2014, 131, 40352. [CrossRef]

98. Zhang, G.; Jiang, S.; Gao, Y.; Sun, F. Regulating photochemical behavior and property of imidazolium-based water soluble polysiloxane macromolecular photoinitiators by anions. J. Photochem. Photobiol. A Chem. 2018, 364, 363-372. [CrossRef]

99. Goering, R.V.; Pattee, P.A. Mutants of Staphylococcus aureus with increased sensitivity to ultraviolet radiation. J. Bacteriol. 1971, 106, 157-161. [CrossRef]

100. Kappes, U.P.; Luo, D.; Potter, M.; Schulmeister, K.; Rünger, T.M. Short- and long-wave UV light (UVB and UVA) induce similar mutations in human skin cells. J. Invest. Dermatol. 2006, 126, 667-675. [CrossRef]

101. Kielbassa, C.; Roza, L.; Epe, B. Wavelength dependence of oxidative DNA damage induced by UV and visible light. Carcinogenesis 1997, 18, 811-816. [CrossRef] [PubMed]

102. Haraguchi, K.; Takada, T. Synthesis and characteristics of nanocomposite gels prepared by in situ photopolymerization in an aqueous system. Macromolecules 2010, 43, 4294-4299. [CrossRef]

103. Mironi-Harpaz, I.; Wang, D.Y.; Venkatraman, S.; Seliktar, D. Photopolymerization of cell-encapsulating hydrogels: Crosslinking efficiency versus cytotoxicity. Acta Biomater. 2012, 8, 1838-1848. [CrossRef]

104. Bryant, S.J.; Nuttelman, C.R.; Anseth, K.S. Cytocompatibility of UV and visible light photoinitiating systems on cultured NIH/3T3 fibroblasts in vitro. J. Biomater. Sci. Polym. Ed. 2000, 11, 439-457. [CrossRef] [PubMed]

105. Sanches-Silva, A.; Andre, C.; Castanheira, I.; Cruz, J.M.; Pastorelli, S.; Simoneau, C.; Paseiro-Losada, P. Study of the migration of photoinitiators used in printed food-packaging materials into food simulants. J. Agric. Food Chem. 2009, 57, 9516-9523. [CrossRef] [PubMed]

106. Williams, C.G.; Malik, A.N.; Kim, T.K.; Manson, P.N.; Elisseeff, J.H. Variable cytocompatibility of six cell lines with photoinitiators used for polymerizing hydrogels and cell encapsulation. Biomaterials 2005, 26, 1211-1218. [CrossRef] [PubMed]

107. Allen, N.S.; Marin, M.C.; Edge, M.; Davies, D.W.; Garrett, J.; Jones, F.; Navaratnam, S.; Parsons, B.J. Photochemistry and photoinduced chemical crosslinking activity of type I \& II co-reactive photoinitiators in acrylated prepolymers. J. Photochem. Photobiol. A Chem. 1999, 126, 135-149. 
108. Bahney, C.S.; Lujan, T.J.; Hsu, C.W.; Bottlang, M.; West, J.L.; Johnstone, B. Visible light photoinitiation of mesenchymal stem cell-laden bioresponsive hydrogels. Eur. Cells Mater. 2011, 22, 43-55. [CrossRef] [PubMed]

109. Marchioli, G.; Zellner, L.; Oliveira, C.; Engelse, M.; Koning, E.d.; Mano, J.K.; Apeldoorn, J.; Moroni, L. Layered PEGDA hydrogel for islet of Langerhans encapsulation and improvement of vascularization. J. Mater. Sci. Mater. Med. 2017, 28. [CrossRef] [PubMed]

110. Liu, S.; Yeo, D.C.; Wiraja, C.; Tey, H.L.; Mrksich, M.; Xu, C. Peptide delivery with poly(ethylene glycol) diacrylate microneedles through swelling effect. Bioeng. Transl. Med. 2017, 2, 258-267. [CrossRef]

111. Aimetti, A.A.; Machen, A.J.; Anseth, K.S. Poly(ethylene glycol) hydrogels formed by thiol-ene photopolymerization for enzyme-responsive protein delivery. Biomaterials 2009, 30, 6048-6054. [CrossRef] [PubMed]

112. Buwalda, S.J.; Perez, L.B.; Teixeira, S.; Calucci, L.; Forte, C.; Feijen, J.; Dijkstra, P.J. Self-assembly and photo-cross-linking of eight-armed PEG-PTMC star block copolymers. Biomacromolecules 2011, 12, 2746-2754. [CrossRef] [PubMed]

113. Wei, M.; Gao, Y.; Jiang, S.; Nie, J.; Sun, F. Design of photoinitiator-functionalized hydrophilic nanogels with uniform size and excellent biocompatibility. Polym. Chem. 2019, 10, 2812-2821. [CrossRef]

114. Assmann, A.; Vegh, A.; Ghasemi-Rad, M.; Bagherifard, S.; Cheng, G.; Sani, E.S.; Ruiz-Esparza, G.U.; Noshadi, I.; Lassaletta, A.D.; Gangadharan, S.; et al. A highly adhesive and naturally derived sealant. Biomaterials 2017, 140, 115-127. [CrossRef] [PubMed]

115. Zhang, Y.S.; Davoudi, F.; Walch, P.; Manbachi, A.; Luo, X.; Dell’Erba, V.; Miri, A.K.; Albadawi, H.; Arneri, A.; $\mathrm{Li}, \mathrm{X}$; et al. Bioprinted thrombosis-on-a-chip. Lab Chip 2016, 16, 4097-4105. [CrossRef] [PubMed]

116. Yu, J.; Zhang, Y.; Sun, W.; Wang, C.; Ranson, D.; Ye, Y.; Weng, Y.; Gu, Z. Internalized compartments encapsulated nanogels for targeted drug delivery. Nanoscale 2016, 8, 9178-9184. [CrossRef] [PubMed]

117. Bryant, S.J.; Bender, R.J.; Durand, K.L.; Anseth, K.S. Encapsulating chondrocytes in degrading PEG hydrogels with high modulus: Engineering gel structural changes to facilitate cartilaginous tissue production. Biotechnol. Bioeng. 2004, 86, 747-755. [CrossRef]

118. Kamoun, E.A.; Omer, A.M.; Abu-Serie, M.M.; Khattab, S.N.; Ahmed, H.M.; Elbardan, A.A. Photopolymerized PVA-g-GMA Hydrogels for Biomedical Applications: Factors Affecting Hydrogel Formation and Bioevaluation Tests. Arab. J. Sci. Eng. 2018, 43, 3565-3575. [CrossRef]

119. Chen, R.T.; Marchesan, S.; Evans, R.A.; Styan, K.E.; Such, G.K.; Postma, A.; McLean, K.M.; Muir, B.W.; Caruso, F. Photoinitiated alkyne-azide click and radical cross-linking reactions for the patterning of PEG hydrogels. Biomacromolecules 2012, 13, 889-895. [CrossRef]

120. Schmedlen, R.H.; Masters, K.S.; West, J.L. Photocrosslinkable polyvinyl alcohol hydrogels that can be modified with cell adhesion peptides for use in tissue engineering. Biomaterials 2002, 23, 4325-4332. [CrossRef]

121. Burdick, J.A.; Anseth, K.S. Photoencapsulation of osteoblasts in injectable RGD-modified PEG hydrogels for bone tissue engineering. Biomaterials 2002, 23, 4315-4323. [CrossRef]

122. Burdick, J.A.; Mason, M.N.; Hinman, A.D.; Thorne, K.; Anseth, K.S. Delivery of osteoinductive growth factors from degradable PEG hydrogels influences osteoblast differentiation and mineralization. J. Control. Release 2002, 83, 53-63. [CrossRef]

123. Nuttelman, C.R.; Tripodi, M.C.; Anseth, K.S. Synthetic hydrogel niches that promote hMSC viability. Matrix Biol. 2005, 24, 208-218. [CrossRef] [PubMed]

124. Masters, K.S.; Shah, D.N.; Walker, G.; Leinwand, L.A.; Anseth, K.S. Designing scaffolds for valvular interstitial cells: Cell adhesion and function on naturally derived materials. J. Biomed. Mater. Res. Part A 2004, 71, 172-180. [CrossRef] [PubMed]

125. Bryant, S.J.; Durand, K.L.; Anseth, K.S. Manipulations in hydrogel chemistry control photoencapsulated chondrocyte behavior and their extracellular matrix production. J. Biomed. Mater. Res. Part A 2003, 67, 1430-1436. [CrossRef]

126. Bryant, S.J.; Chowdhury, T.T.; Lee, D.A.; Bader, D.L.; Anseth, K.S. Crosslinking density influences chondrocyte metabolism in dynamically loaded photocrosslinked poly(ethylene glycol) hydrogels. Ann. Biomed. Eng. 2004, 32, 407-417. [CrossRef]

127. Masters, K.S.; Shah, D.N.; Leinwand, L.A.; Anseth, K.S. Crosslinked hyaluronan scaffolds as a biologically active carrier for valvular interstitial cells. Biomaterials 2005, 26, 2517-2525. [CrossRef] 
128. Alhadlaq, A.; Tang, M.; Mao, J.J. Engineered adipose tissue from human mesenchymal stem cells maintains predefined shape and dimension: Implications in soft tissue augmentation and reconstruction. Tissue Eng. 2005, 11, 556-566. [CrossRef]

129. Liska, R.; Knaus, S.; Gruber, H.; Wendrinsky, J. Carbohydrate modified photoinitiators. JOCCA Surf. Coatings Int. 2000, 83, 297-303. [CrossRef]

130. Kojima, K.; Ito, M.; Morishita, H.; Hayashi, N. A Novel Water-Soluble Photoinitiator for the Acrylic Photopolymerization Type Resist System. Chem. Mater. 1998, 10, 3429-3433. [CrossRef]

131. Atry, F.; Rentchler, E.; Alkmin, S.; Dai, B.; Li, B.; Eliceiri, K.W.; Campagnola, P.J. Parallel multiphoton excited fabrication of tissue engineering scaffolds using a diffractive optical element. Opt. Express 2020, $28,2744$. [CrossRef] [PubMed]

132. Serien, D.; Kawano, H.; Miyawaki, A.; Midorikawa, K.; Sugioka, K. Femtosecond Laser Direct Write Integration of Multi-Protein Patterns and 3D Microstructures into 3D Glass Microfluidic Devices. Appl. Sci. 2018, 8, 147. [CrossRef]

133. Serien, D.; Sugioka, K. Three-Dimensional Printing of Pure Proteinaceous Microstructures by Femtosecond Laser Multiphoton Cross-Linking. ACS Biomater. Sci. Eng. 2020, 6, 1279-1287. [CrossRef]

134. Ullrich, G.; Ganster, B.; Salz, U.; Moszner, N.; Liska, R. Photoinitiators with functional groups. IX. Hydrophilic bisacylphosphine oxides for acidic aqueous formulations. J. Polym. Sci. Part A Polym. Chem. 2006, 44, 1686-1700. [CrossRef]

135. Sodré, C.S.; Albuquerque, P.P.A.C.; Isolan, C.P.; Moraes, R.R.; Schneider, L.F. Relative photon absorption determination and the influence of photoinitiator system and water content on $\mathrm{C}=\mathrm{C}$ conversion, water sorption/solubility of experimental self-etch adhesives. Int. J. Adhes. Adhes. 2015, 63, 152-157. [CrossRef]

136. Majima, T.; Schnabel, W.; Weber, W. Phenyl-2,4,6-trimethylbenzoylphosphinates as water-soluble photoinitiators. Generation and reactivity of $\mathrm{O} \cdot \dot{\mathrm{P}}(\mathrm{C} 6 \mathrm{H} 5)(\mathrm{O}-)$ radical anions. Makromol. Chemie 1991, 192, 2307-2315. [CrossRef]

137. Fairbanks, B.D.; Schwartz, M.P.; Bowman, C.N.; Anseth, K.S. Photoinitiated polymerization of PEG-diacrylate with lithium phenyl-2,4,6-trimethylbenzoylphosphinate: polymerization rate and cytocompatibility. Biomaterials 2009, 30, 6702-6707. [CrossRef]

138. Gou, M.; Qu, X.; Zhu, W.; Xiang, M.; Yang, J.; Zhang, K.; Wei, Y.; Chen, S. Bio-inspired detoxification using 3d-printed hydrogel nanocomposites. Nat. Commun. 2014, 5, 1-9. [CrossRef]

139. Calderon, G.A.; Thai, P.; Hsu, C.W.; Grigoryan, B.; Gibson, S.M.; Dickinson, M.E.; Miller, J.S. Tubulogenesis of co-cultured human iPS-derived endothelial cells and human mesenchymal stem cells in fibrin and gelatin methacrylate gels. Biomater. Sci. 2017, 5, 1652-1660. [CrossRef]

140. Lin, H.; Zhang, D.; Alexander, P.G.; Yang, G.; Tan, J.; Cheng, A.W.M.; Tuan, R.S. Application of visible light-based projection stereolithography for live cell-scaffold fabrication with designed architecture. Biomaterials 2013, 34, 331-339. [CrossRef]

141. Raza, A.; Lin, C.C. The influence of matrix degradation and functionality on cell survival and morphogenesis in PEG-based hydrogels. Macromol. Biosci. 2013, 13, 1048-1058. [CrossRef]

142. Benedikt, S.; Wang, J.; Markovic, M.; Moszner, N.; Dietliker, K.; Ovsianikov, A.; Grützmacher, H.; Liska, R. Highly efficient water-soluble visible light photoinitiators. J. Polym. Sci. Part A Polym. Chem. 2016, 54, 473-479. [CrossRef]

143. Müller, G.; Zalibera, M.; Gescheidt, G.; Rosenthal, A.; Santiso-Quinones, G.; Dietliker, K.; Grützmacher, H. Simple One-Pot Syntheses of Water-Soluble Bis(acyl)phosphane Oxide Photoinitiators and Their Application in Surfactant-Free Emulsion Polymerization. Macromol. Rapid Commun. 2015, 36, 553-557. [CrossRef]

144. Markovic, M.; Van Hoorick, J.; Hölzl, K.; Tromayer, M.; Gruber, P.; Nürnberger, S.; Dubruel, P.; Van Vlierberghe, S.; Liska, R.; Ovsianikov, A. Hybrid Tissue Engineering Scaffolds by Combination of Three-Dimensional Printing and Cell Photoencapsulation. J. Nanotechnol. Eng. Med. 2015, 6, 0210011-0210017. [CrossRef] [PubMed]

145. Wang, J.; Stanic, S.; Altun, A.A.; Schwentenwein, M.; Dietliker, K.; Jin, L.; Stampfl, J.; Baudis, S.; Liska, R.; Grützmacher, H. A highly efficient waterborne photoinitiator for visible-light-induced three-dimensional printing of hydrogels. Chem. Commun. 2018, 54, 920-923. [CrossRef] [PubMed]

146. Pawar, A.A.; Saada, G.; Cooperstein, I.; Larush, L.; Jackman, J.A.; Tabaei, S.R.; Cho, N.J.; Magdassi, S. High-performance 3D printing of hydrogels by water-dispersible photoinitiator nanoparticles. Sci. Adv. 2016, 2, e1501381. [CrossRef] [PubMed] 
147. Zhang, B.; Li, S.; Hingorani, H.; Serjouei, A.; Larush, L.; Pawar, A.A.; Goh, W.H.; Sakhaei, A.H.; Hashimoto, M.; Kowsari, K.; et al. Highly stretchable hydrogels for UV curing based high-resolution multimaterial 3D printing. J. Mater. Chem. B 2018, 6, 3246-3253. [CrossRef] [PubMed]

148. Occhetta, P.; Sadr, N.; Piraino, F.; Redaelli, A.; Moretti, M.; Rasponi, M. Fabrication of 3D cell-laden hydrogel microstructures through photo-mold patterning. Biofabrication 2013, 5, 035002. [CrossRef]

149. Occhetta, P.; Visone, R.; Russo, L.; Cipolla, L.; Moretti, M.; Rasponi, M. VA-086 methacrylate gelatine photopolymerizable hydrogels: A parametric study for highly biocompatible 3D cell embedding. J. Biomed. Mater. Res. Part A 2015, 103, 2109-2117. [CrossRef]

150. Wang, Z.; Jin, X.; Dai, R.; Holzman, J.F.; Kim, K. An ultrafast hydrogel photocrosslinking method for direct laser bioprinting. RSC Adv. 2016, 6, 21099-21104. [CrossRef]

151. Han, W.T.; Jang, T.; Chen, S.; Chong, L.S.H.; Jung, H.D.; Song, J. Improved cell viability for large-scale biofabrication with photo-crosslinkable hydrogel systems through a dual-photoinitiator approach. Biomater. Sci. 2020, 8, 450-461. [CrossRef] [PubMed]

152. Encinas, M.V.; Rufs, A.M.; Bertolotti, S.G.; Previtali, C.M. Xanthene dyes/amine as photoinitiators of radical polymerization: A comparative and photochemical study in aqueous medium. Polymer 2009, 50, 2762-2767. [CrossRef]

153. Neckers, D.C.; Hassoon, S.; Klimtchuk, E. Photochemistry and photophysics of hydroxyfluorones and xanthenes. J. Photochem. Photobiol. A Chem. 1996, 95, 33-39. [CrossRef]

154. Cruise, G.M.; Hegre, O.D.; Scharp, D.S.; Hubbell, J.A. A sensitivity study of the key parameters in the interfacial photopolymerization of poly(ethylene glycol) diacrylate upon porcine islets. Biotechnol. Bioeng. 1998, 57, 655-665. [CrossRef]

155. Fouassier, J.P.; Chesneau, E. Polymérisation induite sous irradiation laser visible, $4 . \quad$ Le système éosine/photoamorceur ultra-violet/amine. Die Makromol. Chemie 1991, 192, 245-260. [CrossRef]

156. Sawhney, A.S.; Pathak, C.P.; Hubbell, J.A. Interfacial photopolymerization of poly(ethylene glycol)-based hydrogels upon alginate-poly(l-lysine) microcapsules for enhanced biocompatibility. Biomaterials 1993, 14, 1008-1016. [CrossRef]

157. Valdes-Aguilera, O.; Pathak, C.P.; Shi, J.; Watson, D.; Neckers, D.C. Photopolymerization Studies Using Visible Light Photoinitiators. Macromolecules 1992, 25, 541-547. [CrossRef]

158. Avens, H.J.; Randle, T.J.; Bowman, C.N. Polymerization behavior and polymer properties of eosin-mediated surface modification reactions. Polymer 2008, 49, 4762-4768. [CrossRef]

159. Desmangles, A.I.; Jordan, O.; Marquis-Weible, F. Interfacial photopolymerization of beta-cell clusters: approaches to reduce coating thickness using ionic and lipophilic dyes. Biotechnol. Bioeng. 2001, 72, 634-641. [CrossRef]

160. Elbert, D.L.; Hubbell, J.A. Conjugate addition reactions combined with free-radical cross-linking for the design of materials for tissue engineering. Biomacromolecules 2001, 2, 430-441. [CrossRef]

161. Nachlas, A.L.Y.; Li, S.; Jha, R.; Singh, M.; Xu, C.; Davis, M.E. Human iPSC-derived mesenchymal stem cells encapsulated in PEGDA hydrogels mature into valve interstitial-like cells. Acta Biomater. 2018, 71, 235-246. [CrossRef] [PubMed]

162. Kizilel, S.; Pérez-Luna, V.H.; Teymour, F. Photopolymerization of poly(ethylene glycol) diacrylate on eosin-functionalized surfaces. Langmuir 2004, 20, 8652-8658. [CrossRef] [PubMed]

163. Erkoc, P.; Seker, F.; Bagci-Onder, T.; Kizilel, S. Gelatin Methacryloyl Hydrogels in the Absence of a Crosslinker as 3D Glioblastoma Multiforme (GBM)-Mimetic Microenvironment. Macromol. Biosci. 2018, 18. [CrossRef] [PubMed]

164. Shih, H.; Lin, C.C. Visible-light-mediated thiol-ene hydrogelation using eosin-Y as the only photoinitiator. Macromol. Rapid Commun. 2013, 34, 269-273. [CrossRef] [PubMed]

165. Kim, S.H.; Chu, C.C. Visible light induced dextran-methacrylate hydrogel formation using (-)-riboflavin vitamin B2 as a photoinitiator and L-arginine as a co-initiator. Fibers Polym. 2009, 10, 14-20. [CrossRef]

166. Sikorska, E.; Khmelinskii, I.; Komasa, A.; Koput, J.; Ferreira, L.F.V.; Herance, J.R.; Bourdelande, J.L.; Williams, S.L.; Worrall, D.R.; Insińska-Rak, M.; et al. Spectroscopy and photophysics of flavin related compounds: Riboflavin and iso-(6,7)-riboflavin. Chem. Phys. 2005, 314, 239-247. [CrossRef]

167. Wollensak, G.; Spoerl, E.; Seiler, T. Riboflavin/ultraviolet-A-induced collagen crosslinking for the treatment of keratoconus. Am. J. Ophthalmol. 2003, 135, 620-627. [CrossRef] 
168. Bertolotti, S.G.; Previtali, C.M.; Rufs, A.M.; Encinas, M.V. Riboflavin/triethanolamine as photoinitiator system of vinyl polymerization. A mechanistic study by laser flash photolysis. Macromolecules 1999, 32, 2920-2924. [CrossRef]

169. Encinas, M.V.; Rufs, A.M.; Bertolotti, S.; Previtali, C.M. Free radical polymerization photoinitiated by riboflavin/amines. Effect of the amine structure. Macromolecules 2001, 34, 2845-2847. [CrossRef]

170. Orellana, B.; Rufs, A.M.; Encinas, M.V.; Previtali, C.M.; Bertolotti, S. The photoinitiation mechanism of vinyl polymerization by riboflavin/ triethanolamine in aqueous medium. Macromolecules 1999, 32, 6570-6573. [CrossRef]

171. Nguyen, A.K.; Gittard, S.D.; Koroleva, A.; Schlie, S.; Gaidukeviciute, A.; Chichkov, B.N.; Narayan, R.J. Two-photon polymerization of polyethylene glycol diacrylate scaffolds with riboflavin and triethanolamine used as a water-soluble photoinitiator. Regen. Med. 2013, 8, 725-738. [CrossRef] [PubMed]

172. Kim, S.H.; Chu, C.C. Fabrication of a biodegradable polysaccharide hydrogel with riboflavin, vitamin B2, as a photo-initiator and L-arginine as coinitiator upon UV irradiation. J. Biomed. Mater. Res. Part B Appl. Biomater. 2009, 91, 390-400. [CrossRef] [PubMed]

173. Batchelor, R.R.; Kwandou, G.; Spicer, P.T.; Stenzel, M.H. Riboflavin (vitamin B2) and flavin mononucleotide as visible light photo initiators in the thiol-ene polymerisation of PEG-based hydrogels. Polym. Chem. 2017, 8, 980-984. [CrossRef]

174. Choe, E.; Huang, R.; Min, D.B. Chemical reactions and stability of riboflavin in foods. J. Food Sci. $2005,70$. [CrossRef]

175. Schnellbaecher, A.; Binder, D.; Bellmaine, S.; Zimmer, A. Vitamins in cell culture media: Stability and stabilization strategies. Biotechnol. Bioeng. 2019, 116, 1537-1555. [CrossRef]

176. Park, Y.J.; Chae, K.H.; Rawls, H.R. Development of a new photoinitiation system for dental light-cure composite resins. Dent. Mater. 1999, 15, 120-127. [CrossRef]

177. Kamoun, E.A.; Menzel, H. HES-HEMA nanocomposite polymer hydrogels: Swelling behavior and characterization. J. Polym. Res. 2012, 19, 1-14. [CrossRef]

178. Jakubiak, J.; Allonas, X.; Fouassier, J.P.; Sionkowska, A.; Andrzejewska, E.; Linden, L.Å.; Rabek, J.F. Camphorquinone-amines photoinitating systems for the initiation of free radical polymerization. Polymer 2003, 44, 5219-5226. [CrossRef]

179. Pande, C.S.; Bassi, D.; Jain, N.; Dhar, A.; Glass, J.D. Diketopinic acid-A novel reagent for the modification of arginine. J. Biosci. 1991, 16, 127-135. [CrossRef]

180. Kamoun, E.A.; El-Betany, A.; Menzel, H.; Chen, X. Influence of photoinitiator concentration and irradiation time on the crosslinking performance of visible-light activated pullulan-HEMA hydrogels. Int. J. Biol. Macromol. 2018, 120, 1884-1892. [CrossRef]

181. Burdick, J.A.; Mason, M.N.; Anseth, K.S. In situ forming lactic acid based orthopaedic biomaterials: Influence of oligomer chemistry on osteoblast attachment and function. J. Biomater. Sci. Polym. Ed. 2001, 12, 1253-1265. [CrossRef] [PubMed]

182. Declercq, H.A.; Gorski, T.L.; Tielens, S.P.; Schacht, E.H.; Cornelissen, M.J. Encapsulation of osteoblast seeded microcarriers into injectable, photopolymerizable three-dimensional scaffolds based on D,L-lactide and $\varepsilon$-caprolactone. Biomacromolecules 2005, 6, 1608-1614. [CrossRef] [PubMed]

183. Wang, Y.; Spencer, P.; Yao, X.; Ye, Q. Effect of coinitiator and wafer on the photoreactivity and photopolymerization of HEMA/camphoquinone-based reactant mixtures. J. Biomed. Mater. Res. Part A 2006, 78, 721-728. [CrossRef] [PubMed]

184. Kamoun, E.A.; Winkel, A.; Eisenburger, M.; Menzel, H. Carboxylated camphorquinone as visible-light photoinitiator for biomedical application: Synthesis, characterization, and application Carboxylated camphorquinone as visible-light photoinitiator. Arab. J. Chem. 2016, 9, 745-754. [CrossRef]

185. Matsuda, T.; Magoshi, T. Preparation of vinylated polysaccharides and photofabrication of tubular scaffolds as potential use in tissue engineering. Biomacromolecules 2002, 3, 942-950. [CrossRef]

186. Nakayama, Y.; Ji-Youn, K.; Nishi, S.; Ueno, H.; Matsuda, T. Development of high-performance stent: gelatinous photogel-coated stent that permits drug delivery and gene transfer. J. Biomed. Mater. Res. 2001, 57, 559-566. [CrossRef]

187. Okino, H.; Nakayama, Y.; Tanaka, M.; Matsuda, T. In situ hydrogelation of photocurable gelatin and drug release. J. Biomed. Mater. Res. 2002, 59, 233-245. [CrossRef] 
188. Okino, H.; Manabe, T.; Tanaka, M.; Matsuda, T. Novel therapeutic strategy for prevention of malignant tumor recurrence after surgery: Local delivery and prolonged release of adenovirus immobilized in photocured, tissue-adhesive gelatinous matrix. J. Biomed. Mater. Res. Part A 2003, 66, 643-651. [CrossRef]

189. Almeida, S.M.; Meereis, C.T.W.; Leal, F.B.; Carvalho, R.V.; Boeira, P.O.; Chisini, L.A.; Cuevas-Suárez, C.E.; Lima, G.S.; Piva, E. Evaluation of alternative photoinitiator systems in two-step self-etch adhesive systems. Dent. Mater. 2020, 36, e29-e37. [CrossRef]

190. Davis, K.A.; Burdick, J.A.; Anseth, K.S. Photoinitiated crosslinked degradable copolymer networks for tissue engineering applications. Biomaterials 2003, 24, 2485-2495. [CrossRef]

191. Poshusta, A.K.; Anseth, K.S. Photopolymerized biomaterials for application in the temporomandibular joint. Proc. Cells Tissues Organs 2001, 169, 272-278.

192. Lapchak, P.A. Transcranial near-infrared laser therapy applied to promote clinical recovery in acute and chronic neurodegenerative diseases. Expert Rev. Med. Devices 2012, 9, 71-83. [CrossRef]

193. Tsai, C.-L.; Chen, J.-C.; Wang, W.-J. Near-infrared Absorption Property of Biological Soft Tissue Constituents. J. Med. Biol. Eng. 2001, 21, 7-13.

194. Kawata, S.; Sun, H.B.; Tanaka, T.; Takada, K. Finer features for functional microdevices. Nature 2001, 412, 697-698. [CrossRef]

195. Miwa, M.; Juodkazis, S.; Kawakami, T.; Matsuo, S.; Misawa, H. Femtosecond two-photon stereo-lithography. Appl. Phys. A Mater. Sci. Process. 2001, 73, 561-566. [CrossRef]

196. Ovsianikov, A.; Mironov, V.; Stampf, J.; Liska, R. Engineering 3D cell-culture matrices: Multiphoton processing technologies for biological and tissue engineering applications. Expert Rev. Med. Devices 2012, 9, 613-633. [CrossRef] [PubMed]

197. Xing, J.F.; Zheng, M.L.; Duan, X.M. Two-photon polymerization microfabrication of hydrogels: an advanced 3D printing technology for tissue engineering and drug delivery. Chem. Soc. Rev. 2015, 44, 5031-5039. [CrossRef] [PubMed]

198. Heitz, J.; Plamadeala, C.; Wiesbauer, M.; Freudenthaler, P.; Wollhofen, R.; Jacak, J.; Klar, T.A.; Magnus, B.; Köstner, D.; Weth, A.; et al. Bone-forming cells with pronounced spread into the third dimension in polymer scaffolds fabricated by two-photon polymerization. J. Biomed. Mater. Res. Part A 2017, 105, 891-899. [CrossRef] [PubMed]

199. Nguyen, L.H.; Straub, M.; Gu, M. Acrylate-Based Photopolymer for Two-Photon Microfabrication and Photonic Applications. Adv. Funct. Mater. 2005, 15, 209-216. [CrossRef]

200. You, S.; Li, J.; Zhu, W.; Yu, C.; Mei, D.; Chen, S. Nanoscale 3D printing of hydrogels for cellular tissue engineering. J. Mater. Chem. B 2018, 6, 2187-2197. [CrossRef]

201. Li, Z.; Pucher, N.; Cicha, K.; Torgersen, J.; Ligon, S.C.; Ajami, A.; Husinsky, W.; Rosspeintner, A.; Vauthey, E.; Naumov, S.; et al. A straightforward synthesis and structure-activity relationship of highly efficient initiators for two-photon polymerization. Macromolecules 2013, 46, 352-361. [CrossRef]

202. Jhaveri, S.J.; McMullen, J.D.; Sijbesma, R.; Tan, L.S.; Zipfel, W.; Ober, C.K. Direct three-dimensional microfabrication of hydrogels via two-photon lithography in aqueous solution. Chem. Mater. 2009, 21, 2003-2006. [CrossRef] [PubMed]

203. Torgersen, J.; Qin, X.-H.; Li, Z.; Ovsianikov, A.; Liska, R.; Stampfl, J. Hydrogels for Two-Photon Polymerization: A Toolbox for Mimicking the Extracellular Matrix. Adv. Funct. Mater. 2013, 23, 4542-4554. [CrossRef]

204. Zhang, W.; Soman, P.; Meggs, K.; Qu, X.; Chen, S. Tuning the poisson's ratio of biomaterials for investigating cellular response. Adv. Funct. Mater. 2013, 23, 3226-3232. [CrossRef] [PubMed]

205. Schafer, K.J.; Hales, J.M.; Balu, M.; Belfield, K.D.; Van Stryland, E.W.; Hagan, D.J. Two-photon absorption cross-sections of common photoinitiators. J. Photochem. Photobiol. A Chem. 2004, 162, 497-502. [CrossRef]

206. Ovsianikov, A.; Deiwick, A.; Van Vlierberghe, S.; Pflaum, M.; Wilhelmi, M.; Dubruel, P.; Chichkov, B. Laser fabrication of 3D gelatin scaffolds for the generation of bioartificial tissues. Mater. Basel 2010, 4, 288-299. [CrossRef]

207. Ovsianikov, A.; Deiwick, A.; Van Vlierberghe, S.; Dubruel, P.; Möller, L.; Drager, G.; Chichkov, B. Laser fabrication of three-dimensional CAD scaffolds from photosensitive gelatin for applications in tissue engineering. Biomacromolecules 2011, 12, 851-858. [CrossRef]

208. Kufelt, O.; El-Tamer, A.; Sehring, C.; Meißner, M.; Schlie-Wolter, S.; Chichkov, B.N. Water-soluble photopolymerizable chitosan hydrogels for biofabrication via two-photon polymerization. Acta Biomater. 2015, 18, 186-195. [CrossRef] 
209. Ovsianikov, A.; Schlie, S.; Ngezahayo, A.; Haverich, A.; Chichkov, B.N. Two-photon polymerization technique for microfabrication of CAD-designed 3D scaffolds from commercially available photosensitive materials. J. Tissue Eng. Regen. Med. 2007, 1, 443-449. [CrossRef]

210. Nava, M.M.; Di Maggio, N.; Zandrini, T.; Cerullo, G.; Osellame, R.; Martin, I.; Raimondi, M.T. Synthetic niche substrates engineered via two-photon laser polymerization for the expansion of human mesenchymal stromal cells. J. Tissue Eng. Regen. Med. 2017, 11, 2836-2845. [CrossRef]

211. Doraiswamy, A.; Jin, C.; Narayan, R.J.; Mageswaran, P.; Mente, P.; Modi, R.; Auyeung, R.; Chrisey, D.B.; Ovsianikov, A.; Chichkov, B. Two photon induced polymerization of organic-inorganic hybrid biomaterials for microstructured medical devices. Acta Biomater. 2006, 2, 267-275. [CrossRef]

212. Doraiswamy, A.; Ovsianikov, A.; Gittard, S.D.; Monteiro-Riviere, N.A.; Crombez, R.; Montalvo, E.; Shen, W.; Chichkov, B.N.; Narayan, R.J. Fabrication of microneedles using two photon polymerization for transdermal delivery of nanomaterials. J. Nanosci. Nanotechnol. 2010, 10, 6305-6312. [CrossRef] [PubMed]

213. Farsari, M.; Filippidis, G.; Sambani, K.; Drakakis, T.S.; Fotakis, C. Two-photon polymerization of an Eosin Y-sensitized acrylate composite. J. Photochem. Photobiol. A Chem. 2006, 181, 132-135. [CrossRef]

214. Campagnola, P.J.; Delguidice, D.M.; Epling, G.A.; Hoffacker, K.D.; Howell, A.R.; Pitts, J.D.; Goodman, S.L. 3-dimensional submicron polymerization of acrylamide by multiphoton excitation of xanthene dyes. Macromolecules 2000, 33, 1511-1513. [CrossRef]

215. Pitts, J.D.; Campagnola, P.J.; Epling, G.A.; Goodman, S.L. Submicron multiphoton free-form fabrication of proteins and polymers: studies of reaction efficiencies and applications in sustained release. Macromolecules 2000, 33, 1514-1523. [CrossRef]

216. Cunningham, L.P.; Veilleux, M.P.; Campagnola, P.J. Freeform multiphoton excited microfabrication for biological applications using a rapid prototyping CAD-based approach. Opt. Express 2006, 14, 8613. [CrossRef] [PubMed]

217. Engelhardt, S.; Hoch, E.; Borchers, K.; Meyer, W.; Krüger, H.; Tovar, G.E.M.; Gillner, A. Fabrication of 2D protein microstructures and 3D polymer-protein hybrid microstructures by two-photon polymerization. Biofabrication 2011, 3, 025003. [CrossRef] [PubMed]

218. Basu, S.; Rodionov, V.; Terasaki, M.; Campagnola, P.J. Multiphoton-excited microfabrication in live cells via Rose Bengal cross-linking of cytoplasmic proteins. Opt. Lett. 2005, 30, 159. [CrossRef]

219. Pitts, J.D.; Howell, A.R.; Taboada, R.; Banerjee, I.; Wang, J.; Goodman, S.L.; Campagnola, P.J. New photoactivators for multiphoton excited three-dimensional submicron cross-linking of proteins: bovine serum albumin and type 1 collagen. Photochem. Photobiol. 2002, 76, 135-144. [CrossRef]

220. Tromayer, M.; Gruber, P.; Markovic, M.; Rosspeintner, A.; Vauthey, E.; Redl, H.; Ovsianikov, A.; Liska, R. A biocompatible macromolecular two-photon initiator based on hyaluronan. Polym. Chem. 2017, 8, 451-460. [CrossRef]

221. Woo, H.Y.; Liu, B.; Kohler, B.; Korystov, D.; Mikhailovsky, A.; Bazan, G.C. Solvent effects on the two-photon absorption of distyrylbenzene chromophores. J. Am. Chem. Soc. 2005, 127, 14721-14729. [CrossRef]

222. Torgersen, J.; Ovsianikov, A.; Mironov, V.; Pucher, N.; Qin, X.; Li, Z.; Cicha, K.; Machacek, T.; Liska, R.; Jantsch, V.; et al. Photo-sensitive hydrogels for three-dimensional laser microfabrication in the presence of whole organisms. J. Biomed. Opt. 2012, 17, 105008. [CrossRef] [PubMed]

223. Qin, X.-H.; Torgersen, J.; Saf, R.; Mühleder, S.; Pucher, N.; Ligon, S.C.; Holnthoner, W.; Redl, H.; Ovsianikov, A.; Stampfl, J.; et al. Three-dimensional microfabrication of protein hydrogels via two-photon-excited thiol-vinyl ester photopolymerization. J. Polym. Sci. Part A Polym. Chem. 2013, 51, 4799-4810. [CrossRef]

224. Wan, X.; Zhao, Y.; Xue, J.; Wu, F.; Fang, X. Water-soluble benzylidene cyclopentanone dye for two-photon photopolymerization. J. Photochem. Photobiol. A Chem. 2009, 202, 74-79. [CrossRef]

225. Li, Z.; Torgersen, J.; Ajami, A.; Mühleder, S.; Qin, X.; Husinsky, W.; Holnthoner, W.; Ovsianikov, A.; Stampfl, J.; Liska, R. Initiation efficiency and cytotoxicity of novel water-soluble two-photon photoinitiators for direct 3D microfabrication of hydrogels. RSC Adv. 2013, 3, 15939-15946. [CrossRef]

226. Ovsianikov, A.; Mühleder, S.; Torgersen, J.; Li, Z.; Qin, X.H.; Van Vlierberghe, S.; Dubruel, P.; Holnthoner, W.; Redl, H.; Liska, R.; et al. Laser photofabrication of cell-containing hydrogel constructs. Langmuir 2014, 30, 3787-3794. [CrossRef]

227. Yang, W.; Zou, Q.; Zhou, Y.; Zhao, Y.; Huang, N.; Gu, Y.; Wu, F. Carboxylate modified benzylidene cyclopentanone dyes for one- and two-photon excited photodynamic therapy. J. Photochem. Photobiol. A Chem. 2011, 222, 228-235. [CrossRef] 
228. Fang, Y.; Liu, T.; Zou, Q.; Zhao, Y.; Wu, F. Cationic benzylidene cyclopentanone photosensitizers for selective photodynamic inactivation of bacteria over mammalian cells. RSC Adv. 2015, 5, 56067-56074. [CrossRef]

229. Huang, X.; Wang, X.; Zhao, Y. Study on a series of water-soluble photoinitiators for fabrication of 3D hydrogels by two-photon polymerization. Dye. Pigment. 2017, 141, 413-419. [CrossRef]

230. Wenz, G. Cyclodextrine als Bausteine supramolekularer Strukturen und Funktionseinheiten. Angew. Chemie 1994, 106, 851-870. [CrossRef]

231. Tomatsu, I.; Peng, K.; Kros, A. Photoresponsive hydrogels for biomedical applications. Adv. Drug Deliv. Rev. 2011, 63, 1257-1266. [CrossRef]

232. Ko, D.Y.; Shinde, U.P.; Yeon, B.; Jeong, B. Recent progress of in situ formed gels for biomedical applications. Prog. Polym. Sci. 2013, 38, 672-701. [CrossRef]

233. Wang, X.; Wei, Z.; Baysah, C.Z.; Zheng, M.; Xing, J. Biomaterial-based microstructures fabricated by two-photon polymerization microfabrication technology. RSC Adv. 2019, 9, 34472-34480. [CrossRef]

234. Zivic, N.; Zhang, J.; Bardelang, D.; Dumur, F.; Xiao, P.; Jet, T.; Versace, D.L.; Dietlin, C.; Morlet-Savary, F.; Graff, B.; et al. Novel naphthalimide-amine based photoinitiators operating under violet and blue LEDs and usable for various polymerization reactions and synthesis of hydrogels. Polym. Chem. 2016, 7, 418-429. [CrossRef]

235. Balta, D.K.; Bagdatli, E.; Arsu, N.; Ocal, N.; Yagci, Y. Chemical incorporation of thioxanthone into $\beta$-cyclodextrin and its use in aqueous photopolymerization of methyl methacrylate. J. Photochem. Photobiol. A Chem. 2008, 196, 33-37. [CrossRef]

236. Temel, G.; Parali, T.; Tulu, M.; Arsu, N. Photopolymerization of acrylamide with benzophenone/ methylated- $\beta$-cyclodextrin inclusion complex in the presence of jeffamine based dendrimers as coinitiators in aqueous media. J. Photochem. Photobiol. A Chem. 2010, 213, 46-51. [CrossRef]

237. Ayub, N.F.; Hashim, S.; Jamaluddin, J.; Adrus, N. New UV LED curing approach for polyacrylamide and poly(: N -isopropylacrylamide) hydrogels. N. J. Chem. 2017, 41, 5613-5619. [CrossRef]

238. Xing, J.; Liu, J.; Zhang, T.; Zhang, L.; Zheng, M.; Duan, X. A water soluble initiator prepared through host-guest chemical interaction for microfabrication of 3D hydrogels via two-photon polymerization. J. Mater. Chem. B 2014, 2, 4318-4323. [CrossRef]

239. Zuo, X.; Morlet-Savary, F.; Schmitt, M.; Le Nouën, D.; Blanchard, N.; Goddard, J.P.; Lalevée, J. Novel applications of fluorescent brighteners in aqueous visible-light photopolymerization: high performance water-based coating and LED-assisted hydrogel synthesis. Polym. Chem. 2018, 9, 3952-3958. [CrossRef]

240. Abdallah, M.; Hijazi, A.; Graff, B.; Fouassier, J.P.; Rodeghiero, G.; Gualandi, A.; Dumur, F.; Cozzi, P.G.; Lalevée, J. Coumarin derivatives as versatile photoinitiators for $3 \mathrm{D}$ printing, polymerization in water and photocomposite synthesis. Polym. Chem. 2019, 10, 872-884. [CrossRef]

241. Bouzrati-Zerelli, M.; Zivic, N.; Dumur, F.; Gigmes, D.; Graff, B.; Fouassier, J.P.; Lalevée, J. New violet to yellow light sensitive diketo pyrrolo-pyrrole photoinitiators: High performance systems with unusual bleaching properties and solubility in water. Polym. Chem. 2017, 8, 2028-2040. [CrossRef]

242. Staneva, D.; Grabchev, I.; Bosch, P. Fluorescent Hydrogel-Textile Composite Material Synthesized by Photopolymerization. Int. J. Polym. Mater. Polym. Biomater. 2015, 64, 838-847. [CrossRef]

243. Drury, J.L.; Mooney, D.J. Hydrogels for tissue engineering: Scaffold design variables and applications. Biomaterials 2003, 24, 4337-4351. [CrossRef]

244. Nguyen, A.K.; Narayan, R.J. Two-photon polymerization for biological applications. Mater. Today 2017, 20, 314-322. [CrossRef]

245. Seliktar, D. Designing cell-compatible hydrogels for biomedical applications. Science. 2012, 336, 1124-1128. [CrossRef] [PubMed]

246. Qin, X.H.; Ovsianikov, A.; Stampfl, J.; Liska, R. Additive manufacturing of photosensitive Hydrogels for tissue engineering applications. BioNanoMaterials 2014, 15, 49-70. [CrossRef]

247. Kasko, A.M.; Wong, D.Y. Two-photon lithography in the future of cell-based therapeutics and regenerative medicine: A review of techniques for hydrogel patterning and controlled release. Future Med. Chem. 2010, 2, 1669-1680. [CrossRef]

248. Eren, T.N.; Lalevée, J.; Avci, D. Water soluble polymeric photoinitiator for dual-curing of acrylates and methacrylates. J. Photochem. Photobiol. A Chem. 2020, 389, 112288. [CrossRef]

249. Ma, P.X. Biomimetic materials for tissue engineering. Adv. Drug Deliv. Rev. 2008, 60, 184-198. [CrossRef] 
250. Choi, J.R.; Yong, K.W.; Choi, J.Y.; Cowie, A.C. Recent advances in photo-crosslinkable hydrogels for biomedical applications. Biotechniques 2019, 66, 40-53. [CrossRef]

251. Lin, H.; Cheng, A.W.M.; Alexander, P.G.; Beck, A.M.; Tuan, R.S. Cartilage tissue engineering application of injectable gelatin hydrogel with in situ visible-light-activated gelation capability in both air and aqueous solution. Tissue Eng. Part A 2014, 20, 2402-2411. [CrossRef]

252. Fukui, S.; Sonomoto, K.; Itoh, N.; Tanaka, A. Several novel methods for immobilization of enzymes, microbial cells and organelles. Biochimie 1980, 62, 381-386. [CrossRef]

253. Almeida, J.F.; Ferreira, P.; Lopes, A.; Gil, M.H. Photocrosslinkable biodegradable responsive hydrogels as drug delivery systems. Int. J. Biol. Macromol. 2011, 49, 948-954. [CrossRef] [PubMed]

254. Annabi, N.; Rana, D.; Shirzaei Sani, E.; Portillo-Lara, R.; Gifford, J.L.; Fares, M.M.; Mithieux, S.M.; Weiss, A.S. Engineering a sprayable and elastic hydrogel adhesive with antimicrobial properties for wound healing. Biomaterials 2017, 139, 229-243. [CrossRef] [PubMed]

255. Lin, S.; Lee, W.Y.W.; Feng, Q.; Xu, L.; Wang, B.; Man, G.C.W.; Chen, Y.; Jiang, X.; Bian, L.; Cui, L.; et al. Synergistic effects on mesenchymal stem cell-based cartilage regeneration by chondrogenic preconditioning and mechanical stimulation. Stem Cell Res. Ther. 2017, 8, 221. [CrossRef] [PubMed]

256. Masurovsky, E.B.; Peterson, E.R. Photo-reconstituted collagen gel for tissue culture substrates. Exp. Cell Res. 1973, 76, 447-448. [CrossRef]

257. He, C.; Li, F.; Ahn, J.I.; Latorre, M.; Griffith, M. Photo-induced in situ forming hydrogels based on collagen and a biocompatible macromolecular photoinitiator. J. Control. Release 2011, 152 (Suppl. S1). [CrossRef]

258. Anseth, K.S.; Metters, A.T.; Bryant, S.J.; Martens, P.J.; Elisseeff, J.H.; Bowman, C.N. In situ forming degradable networks and their application in tissue engineering and drug delivery. Proc. J. Control. Release 2002, 78, 199-209.

259. Geng, J.; Li, W.; Zhang, Y.; Thottappillil, N.; Clavadetscher, J.; Lilienkampf, A.; Bradley, M. Radical polymerization inside living cells. Nat. Chem. 2019, 11, 578-586. [CrossRef]

260. Yang, J.; Li, J.; Wang, X.; Li, X.; Kawazoe, N.; Chen, G. Single mammalian cell encapsulation by: In situ polymerization. J. Mater. Chem. B 2016, 4, 7662-7668. [CrossRef]

261. Tetsuka, H.; Shin, S.R. Materials and Technical Innovations in 3D Printing in Biomedical Applications. J. Mater. Chem. B 2020. [CrossRef]

262. Gao, G.; Schilling, A.F.; Yonezawa, T.; Wang, J.; Dai, G.; Cui, X. Bioactive nanoparticles stimulate bone tissue formation in bioprinted three-dimensional scaffold and human mesenchymal stem cells. Biotechnol. J. 2014, 9, 1304-1311. [CrossRef]

263. Käpylä, E.; Sedlačík, T.; Aydogan, D.B.; Viitanen, J.; Rypáček, F.; Kellomäki, M. Direct laser writing of synthetic poly(amino acid) hydrogels and poly(ethylene glycol) diacrylates by two-photon polymerization. Mater. Sci. Eng. C 2014, 43, 280-289. [CrossRef] [PubMed]

264. Seidlits, S.K.; Schmidt, C.E.; Shear, J.B. High-resolution patterning of hydrogels in three dimensions using direct-write photofabrication for cell guidance. Adv. Funct. Mater. 2009, 19, 3543-3551. [CrossRef]

265. Gao, G.; Yonezawa, T.; Hubbell, K.; Dai, G.; Cui, X. Inkjet-bioprinted acrylated peptides and PEG hydrogel with human mesenchymal stem cells promote robust bone and cartilage formation with minimal printhead clogging. Biotechnol. J. 2015, 10, 1568-1577. [CrossRef] [PubMed]

266. Tibbitt, M.W.; Shadish, J.A.; DeForest, C.A. Photopolymers for Multiphoton Lithography in Biomaterials and Hydrogels. In Multiphoton Lithography; Wiley-VCH Verlag GmbH \& Co. KGaA: Weinheim, Germany, 2016; pp. 183-220.

267. Wang, Z.; Abdulla, R.; Parker, B.; Samanipour, R.; Ghosh, S.; Kim, K. A simple and high-resolution stereolithography-based 3D bioprinting system using visible light crosslinkable bioinks. Biofabrication 2015, 7, 045009. [CrossRef] [PubMed]

268. Husar, B.; Hatzenbichler, M.; Mironov, V.; Liska, R.; Stampfl, J.; Ovsianikov, A. Photopolymerization-based additive manufacturing for the development of 3D porous scaffolds. In Biomaterials for Bone Regeneration: Novel Techniques and Applications; Elsevier Ltd.: Amsterdam, The Netherlands, 2014; pp. 149-201, ISBN 9780857098108. 
269. Kizilel, S.; Sawardecker, E.; Teymour, F.; Pérez-Luna, V.H. Sequential formation of covalently bonded hydrogel multilayers through surface initiated photopolymerization. Biomaterials 2006, 27, 1209-1215. [CrossRef] [PubMed]

270. Chan, J.M.; Xu, C. Perspectives in Micro- and Nanotechnology for Biomedical Applications; Imperial Collage Press: London, UK, 2016; ISBN 978-1-78326-960-0. 